\title{
GENERATOR LIABILITY UNDER SUPERFUND FOR CLEAN-UP OF ABANDONED HAZARDOUS WASTE DUMPSITES
}

In response to the well-publicized toxic waste problem, Congress recently enacted the Comprehensive Environmental Response, Compensation, and Liability Act of $1980,{ }^{1}$ commonly known as the "Superfund Act." The Superfund Act establishes a $\$ 1.6$ billion "Hazardous Substance Response Trust Fund" 2 to finance prompt government clean-up of abandoned hazardous chemical waste dumpsites. The Act authorizes fund representatives to sue responsible private parties for reimbursement of clean-up costs incurred by the government at each dumpsite. ${ }^{3}$ Largely because the Superfund Act was the product of a last-minute congressional compromise, ${ }^{4}$ however, the precise liability standard it imposes on these responsible parties is unclear.

Due to the nature of the toxic waste disposal industry, in many cases the only solvent, locatable parties with any connection to dumpsites targeted for clean-up under the Act will be chemical companies that, well before Superfund's enactment, generated the toxic wastes contained in those sites. ${ }^{5}$ Although some have argued that invoking Superfund's liability provisions against such generators would be an impermissibly retroactive application of the Act, ${ }^{\circ}$ this Comment concludes that, to the contrary, retroactive application of Superfund to hold pre-enactment hazardous waste generators liable for clean-up costs was intended by Congress and is well within constitutional boundaries. This Comment will also explore the legislative history of the Superfund Act to ascertain the intended scope of the Act's liability provisions when applied to such pre-enactment generators.

I. Background: The Hazardous Waste Problem and THE SUPERFUND "SOLUTION"

\section{A. The Problem}

The United States Environmental Protection Agency (EPA) estimated in 1979 that as many as 30,000 to 50,000 inactive and

1 Pub. L. No. 96-510, 94 Stat. 2767 (codified at 42 U.S.C. \$\$9601-9657 (Supp. IV 1980)).

2 Id. $\$ 9631$.

3 Id. $\$ 9607$.

4 See infra text accompanying notes $62-66$.

5 See infra text accompanying and following note 12.

6 See infra text accompanying notes 28-32. 
uncontrolled hazardous chemical waste sites exist in the United States. ${ }^{7}$ Although toxic chemical wastes are no longer being deposited in these dumpsites, many of them continue to fester, smolder, and leak improperly discarded poisons into the environment. ${ }^{8}$ The EPA has estimated that it will cost $\$ 13.1$ billion to $\$ 22.1$ billion just to clean up the 1200 to 2000 inactive sites posing the greatest danger to the public health and environment.9

Although most hazardous waste generators ${ }^{10}$ disposed of their wastes themselves on their own premises, thereby simplifying the problem of locating the party responsible for improper disposal, approximately twenty to thirty percent of generators have contracted out for disposal in off-site disposal facilities and for transport by independent haulers.11 Of the 1200 to 2000 most dangerous inactive sites, a significant number are abandoned off-site facilities whose owners are either insolvent or impossible to locate. ${ }^{12}$ In addition, the parties who transported and physically dumped the wastes often were independent disposal companiesmiddlemen between the waste generator and the dumpsite ownerwho have also vanished or are insolvent. Thus, the only solvent and locatable party with any connection to the lingering hazardous condition is the chemical company that originally generated the wastes.

Prior to the enactment of Superfund, existing law made the attachment of clean-up liability to such "non-dumping generators" $^{13}$ quite difficult, if not impossible. ${ }^{14}$ Indeed, several con-

7 Hazardous and Toxic Waste Disposal: Joint Hearings on S. 1341 and S. 1480 Before the Subcomms. on Environmental Pollution and Resource Protection of the Senate Comm. on Environment and Public Works, 96th Cong., 1st Sess., pt. 4, at 7 (1979) [hereinafter cited as Senate Hazardous Waste Hearings].

8 The EPA estimated in 1979 that approximately $90 \%$ of all hazardous wastes have been disposed of improperly. See Senate Hazardous Waste Hearings, supra note 7 , pt. 3 , at 72 . Some of the best known examples are the "Love Canal" site in Niagara Falls, N.Y., the "Valley of the Drums" in Shepardsville, Ky., and the "Chemical Control site" in Elizabeth, N.J. H.R. REP. No. 1016, 96th Cong., 2d Sess., pt. I, at 18 (1980). The report, absent the text of the bill, is reprinted in 1980 U.S. Code Cong. \& AD. NEws 6119, 6120.

9 H.R. Rep. No. 1016, supra note 8, at 20, reprinted in 1980 U.S. Code Cong. \& AD. NEws at 6123 .

10 The term "generator" as used in this Comment and by hazardous waste experts refers to chemical manufacturers who produce toxic chemical wastes as a by-product of the chemicals they market.

11 See Senate Hazardous Waste Hearings, supra note 7 , pt. 3 , at 72.

12 Council on Environmental, Quatity, Tenth Annual Report 174 (1979).

13 A "non-dumping generator" is a generator that hired a third party to dispose of its wastes at an off-site facility. A hypothetical discussing such a generator appears infra text following note 32 .

14 See infra text accompanying notes 38-39. 
gressional committees declared in 1980 that existing law was wholly inadequate to address the serious problem of inactive hazardous waste site clean-up.15 The national attention several hazardous waste disasters had received during the late 1970 's, ${ }^{16}$ finally provided the political impetus for a response at the federal level.

\section{B. The Superfund "Solution"}

Congress's answer to the hazardous waste problem was the passage of the Superfund Act. The Act established a $\$ 1.6$ billion "Hazardous Substance Response Trust Fund," 17 to be financed by taxes levied over a five-year period on the oil and chemical industries and by a smaller contribution from the general revenues. ${ }^{18}$ The fund is to be used to finance prompt government clean-up of hazardous waste sites targeted by a "national contingency plan." 19 In the past, the government's lack of any readily available method to finance the clean-up of hazardous waste sites resulted in the postponement of clean-up efforts until after liability was assessed in lengthy litigation against responsible private parties. During litigation, of course, toxic wastes further damaged the environment. In theory, at least, ${ }^{20}$ Superfund will eliminate such delays because

15 H.R. REP. No. 1016, supra note 8, at 18, reprinted in 1980 U.S. CODE Cong. \& Ad. News at 6120; S. Rep. No. 848, 86th Cong., 2d Sess. 10-12 (1980).

16 For example, the "Love Canal" disaster in Niagara Falls, N.Y., involved such serious leakage of hazardous wastes that it became the first non-natural disaster to be declared a national disaster. The tremendous damage and health hazards caused by the Love Canal site were publicized nationally. For a chronology of events surrounding the Love Canal disaster, see 126 Cong. REc. S14,969-71 (daily ed. Nov. 24, 1980) (remarks of Sen. Moynihan).

1742 U.S.C. $\$ 9631$ (Supp. IV 1980).

18 of the estimated $\$ 1.6$ billion fund, approximately $\$ 1.38$ billion will come from taxes imposed on crude oil, petroleum products, and other chemicals that are the raw materials used in many of the processes that generate hazardous wastes. See 26 U.S.C. $\$ \$ 4611,4661$ (Supp. IV 1980). The remaining $\$ 220$ million will come from the general revenues, as appropriated over a five-year period. See 42 U.S.C. \$9631(b) (Supp. IV 1980).

19 See 42 U.S.C. $\$ 9605$ (Supp. IV 1980). This section required the President, within 180 days of the enactment of Superfund, to revise the existing "national contingency plan" (for the removal of oil and hazardous substances) to incorporate the powers created by Superfund. The plan will establish procedures and standards for responding to hazardous waste releases, including methods for discovering, investigating, and cleaning up waste sites. Despite the Act's requirement that a revised plan be adopted by June 1981, such a plan was not adopted until July 12, 1982, after the EPA was compelled by court order to obey the statute. See 13 ENv'r Rep. (BNA) 364-65 (1982); 47 Fed. Reg. 31, 180 (1982).

20 As one commentator has noted, however, implementation of the Superfund Act poses substantial practical and administrative problems. The Act, it is argued, 
the government will have both the authority and the funds to begin clean-up efforts as soon as a hazardous site is targeted. Litigation awards will then be used to replenish the fund.

\section{Problems Regarding Generator Liability}

The importance of replenishing the fund under the Superfund scheme should not be minimized. The fund is of limited size, $^{21}$ and its monies will be exhausted quickly, thwarting future clean-up efforts, unless Superfund's new liability-assessing provisions succeed. The Act authorizes the government to sue responsible private parties to recover the clean-up costs the fund has expended at targeted sites. ${ }^{22}$. Under this liability provision, the government may attempt to recover clean-up costs from waste generators, ${ }^{23}$ dumpsite owners and operators, ${ }^{24}$ and parties who transported waste materials to the dumpsite. ${ }^{25}$ Dumpsite owners and transporters, however, will often prove to be either insolvent or impossible to locate. ${ }^{28}$ Hence, in many cases the success of the government's vital efforts to replenish the fund will depend upon whether the chemical company that generated the wastes can be held liable. This Comment will address the effect of Superfund on such past waste generators.

Part II explores the issue whether Superfund can be applied retroactively to impose liability on pre-enactment waste generators

permits potential targets to stall and possibly even prevent the initiation of government clean-up efforts. See generally Mott, Defenses Under Superfund, 13 Nat. Resources L. Newstetier, May 1981, at 1, 17-19. This Comment will not address the many pre-clean-up administrative difficulties the government will face under Superfund, but will concentrate instead on post-clean-up defenses to liability available to generators.

21 Former Representative Robert C. Eckhardt, who was actively involved in the consideration of the Superfund legislation, has written that the fund is less than half the size of what is needed merely to commence the "gigantic" program of hazardous waste clean-up. Eckhardt, The Unfinished Business of Hazardous Waste Control, 33 Bayzor L. REv. 263 (1981).

2242 U.S.C. $\$ 9607$ (Supp. IV 1980).

23 Id. $\$ 9607$ (a) (3).

24 Id. $\$ 9607$ (a) (2).

$25 I d$. $\$ 9607$ (a) (4). Although the Act thus permits recovery of government clean-up costs from several responsible parties, and also permits recovery of natural resources damages in some circumstances, it has been severely criticized for its failure to permit recovery by private victims for personal damages caused by improper waste disposal. See, e.g., Meyer, Compensating Hazardous Waste Victims: RCRA Insurance Regulations and a Not So "Super"Fund Act, 11 ENviL. L. 689, 701 (1981); Note, Allocating Costs of Hazardous Waste Disposal, 94 Harv. L. REv. 584, 591 (1981).

${ }^{26}$ See supra text accompanying notes $12-13$. 
who acted in full compliance with laws existing when their wastes were generated and disposed of. The Comment demonstrates that the legislative history and relevant constitutional decisions permit the imposition of such retroactive liability. The Act must therefore be analyzed closely to ascertain the liability standard imposed upon these past waste generators. Although several cases have been filed invoking Superfund's liability provisions as a basis for generator liability, ${ }^{27}$ there are no decisions that have comprehensively interpreted these ambiguous provisions. Thus a detailed examination of the statutory language and legislative history of the Act is both necessary and timely. Part III examines Congress's intent regarding the availability and nature of the Act's third party causation defense, and concludes that to avoid liability, many preenactment generators who hired independent contractors to dispose of their wastes need show only that they acted with "due care," while future waste generators who use identical disposal procedures will be strictly liable for damages caused by their wastes. Part IV discusses whether Superfund imposes joint and several liability on responsible generators when, as is typical, each generator's wastes cause an unknown portion of the total damage at a large off-site dump containing toxic wastes from several different sources. This Comment argues that Congress intended to impose joint and several liability in most cases in which individual defendants cannot prove their contribution, but that in limited but important circumstances the courts were left with the power to apportion damages.

After examining these three problems regarding generator liability, the Comment concludes in Part $\mathrm{V}$ that political realities led to weak, ambiguous final language regarding generator liability. Courts that wish to aid in the expeditious clean-up of abandoned dumpsites should not, however, interpret the Act's difficult liability provisions disingenuously in order to find a deep-pocketed party to finance clean-up efforts, but should earnestly attempt to discover the meaning Congress intended for the liability provisions, and apply the Act accordingly.

27 See, e.g., United States v. Reilly Tar \& Chem. Corp., No. 4-80-469 (D. Minn. filed Sept. 4, 1980); United States v. Vertac Chem. Corp., No. LR-C-80-109 (E.D. Ark. filed March 4, 1980); United States v. Melvin Wade, No. 79-1426 (E.D. Pa. filed 1979); United States v. Outboard Marine Corp., No. 78-C-1004 (N.D. Ill. filed 1978). All of these cases originated under the Resource Conservation and Recovery Act of 1976 (Solid Waste Disposal Act), 42 U.S.C. $\$ \$ 6901-$ 6987 (1976 \& Supp. II 1978), but a Superfund count was added after the passage of the Act. 


\section{Are Superfund's Liability Provisions Impermissibly Retroactive If Applied to Pre-enactment Hazardous WASTE GeNERATORS?}

\section{A. Circumstances Giving Rise to a Possible Claim of Impermissible Retroactivity}

Because chemical waste generators may be the only responsible parties not judgment-proof, they are likely targets of government suits to replenish the Superfund. When Congress considered the Superfund Act's liability provisions, the Chemical Manufacturers' Association, ${ }^{28}$ Senators Domenici, Bentsen, and Baker of the Senate Committee on Environment and Public Works, ${ }^{29}$ and Representatives Stockman ${ }^{30}$ and Madigan ${ }^{31}$ protested that retroactive application of these provisions to previously non-negligent parties ${ }^{32}$ would be unfair and possibly unconstitutional. In order to understand the type of situation in which retroactive application of Superfund is alleged to be unconstitutional, consider the following hypothetical case:

In 1974, Chemco, a chemical manufacturing company, produced several tanks of Stickychem, a useftii product with the unfortunate characteristic of leaving highly toxic residues stuck to the walls of the tanks in which it is produced. At the close of the 1974 Stickychem production cycle, Chemco decided to discontinue its production and therefore contracted with Middleman Disposal Company to have the tanks steam-cleaned and the toxic residues disposed of. Chemico paid Middleman, a reputable outfit with a track record of safe disposal, the premium rate for safe cleaning and disposal. Chemco included in its contract with Middleman a provision requiring that the wastes be disposed of in a safe, EPA-certified off-site facility. Middleman, however, was in financial difficulty at the time and eager to make maximum profit on the Chemco operation. So Middleman, unbeknownst to Chemco, subcontracted with Flybynight Dumping Company for the ultimate disposal of the toxic residues. Instead of incurring the higher cost of safely disposing the barrels in a sealed dumpsite, Middleman

28 See Senate Hazardous Waste Hearings, supra note 7 , at 455 .

29 See S. Rep. No. 848, supra rote 15, at 120.

${ }^{30}$ See 126 Cong. REc. H9466-67 (daily ed. Sept. 23, 1980).

31 See id. H9465-66.

32 A previously "non-negligent party" or "non-negligent generator" is one who produced hazardous wastes prior to the enactment of Superfund and complied with all prior existing laws, including common law, in arranging for or carrying out hazardous waste disposal. 
paid Flybynight a modest fee to get rid of the leaky barrels as it pleased. Flybynight took the barrels to an industrial backlot called Quickdump, where they were thrown onto a large, leaking heap not far from a local stream.

Chemco carefully followed all toxic waste disposal procedures required by federal and state law, including common law, as it existed in $1974 . .^{33}$ In 1975, Middleman and Flybynight went out of business, and the owner of Quickdump closed the dump, abandoned the property, and vanished. In 1982, the EPA discovered the highly dangerous inactive dumpsite, and cleaned it up using $\$ 1$ million from Superfund. The EPA then filed suit against Chemco under Section 107 of the Superfund Act ${ }^{34}$ for reimbursement of the government's clean-up costs. Chemco, concerned that it will be held liable under the Act, ${ }^{35}$ now protests that application of Superfund's new liability provisions to hold it responsible for 1974 actions that were perfectly legal when performed is an impermissibly retroactive application of the Act that is unfair, possibly an ex post facto law, and violative of due process.

\section{B. The Need to Apply Superfund Retroactively}

To show that Superfund's liability provisions are impermissibly retroactive, a Chemco-like generator must first establish that the application of those provisions to the facts posited would be a retroactive application. Joseph Story, as a federal judge in New Hampshire, gave the classic definition of retroactivity: "[E]very statute which takes away or impairs vested rights acquired under existing laws, or creates a new obligation, imposes a new duty, or attaches a new disability, in respect to transactions or considerations already past, must be deemed retrospective." 36 Thus, a litigant must demonstrate two things to show that Superfund's application to the situation described above is in fact a retroactive application. First, it must show that Superfund imposes new duties or liabilities, which requires a thorough examination of $38-39$.

33 For further discussion of this contention, see infra text accompanying notes

3442 U.S.C. $\$ 9607$ (Supp. IV 1980).

35 This assumption is probably accurate. For a discussion of whether a Chemco-like generator would ultimately be held liable under the Superfund Act, see infra text accompanying notes 172-76.

36 Society for Propagating the Gospel v. Wheeler, 22 F. Cas. 756, 767 (C.C.D.N.H. 1814) (No. 13,156), quoted in Sturges v. Carter, 114 U.S. 511, 519 (1884). 
prior law. Second, it must show that the Act is being applied to "transactions or considerations already past." 37

Under the first prong of the retroactivity test, legislation that merely duplicates a previous liability scheme does not create a new obligation or duty; such legislation is therefore not retroactive. Thus, Chemco must first show that it could not have been held liable for improper dumping of its wastes under any law existing in 1974. Under the facts described above, Chemco could probably make this showing. ${ }^{38}$ There has been considerable commentary on non-negligent generator liability for hazardous waste clean-up under common law and state and old federal statutes, most of which has concluded that a generator such as Chemco would not have been liable in $1974 . .^{39}$ It is beyond the scope of this Comment to resurvey 1974 hazardous waste law; the important point is that a generator claiming that Superfund is impermissibly retroactive must undertake such a survey to show the court that Superfund does not hold it liable merely for actions for which it would have been already liable under previously existing law.

Under the second prong of the retroactivity test, a law is not considered to be applied retroactively unless it is applied to "trans-

$37 \mathrm{Id}$.

38 See infra note 39 and accompanying text.

Recently, however, state common and statutory law has become much tougher on hazardous waste generators. For example, in 1976, New Jersey declared that under its common law, hazardous waste generation or storage would be considered an "ultrahazardous" activity, and those engaging in such activity would be subject to strict and vicarious liability for any damages traceable to its wastes. Bridgeton v. B.P. Oil, Inc., 146 N.J. Super. 169, 369 A.2d 49 (1976). New Jersey, however, is the only jurisdiction to have explicitly so declared. But several states have recently enacted statutes holding hazardous waste generators strictly liable for damages due to their wastes. See Cohen \& Derkics, Financial Responsibility for Hazardous Waste Sites, 9 CAP. U.L. Rev. 509, 526-44 (1980). In 1976, Congress enacted the Resource Conservation and Recovery Act of 1976 (Solid Waste Disposal Act), 42 U.S.C. $\$ \$ 6901-6987$ (1976 \& Supp. II 1978), which authorizes the EPA to seek an injunction to stop the "handling, storage, treatment, transportation or disposal" of hazardous waste that may present an imminent and subsantial danger to health or the environment. This Act has been used recently as the basis for generator liability for waste clean-up. See cases cited supra note 27. See generally Note, supra note 25, at 593-96; Note, Strict Liability for Generators, Transporters, and Disposers of Hazardous Wastes, 64 MINN. L. Rev. 949, 957-59 (1980).

39 See, e.g., Note, Liability for Generators of Hazardous Waste: The Failure of Existing Enforcement Mechanisms, 69 GEo. L.J. 1047 (1981); Note, Inactive or Abandoned Hazardous Waste Disposal Sites: Coping with a Costly Past, 53 So. CAL. L. REv. 1709 (1980); Note, supra note 38. Although it is arguable that common law doctrine regarding strict liability for ultrahazardous activity may be extended to cover hazardous waste generation, as was done in 1976 in New Jersey, Bridgeton v. B.P. Oil, Inc., 146 N.J. Super. 169, 369 A.2d 49 (1976), all of the articles cited above concede that this is a very recent trend, and that past courts have not held Chemco-like "non-negligent" generators liable under common law or prior federal or state statutory law. 
actions or considerations already past." 40 In several hazardous waste cases litigated under the Resource Conservation and $\mathrm{Re}$ covery Act of 1976 (RCRA), ${ }^{41}$ the government contended that the Act was being applied to a hazardous condition that was currently harming the environment, and that even though the condition was caused by past activities of the defendant, application of RGRA to assess liability for current clean-up of a current condition is not a retroactive application.22 In United States $v$. Diamond Shamrock Corp.,43 the court agreed with this view, holding that RCRA was not applied retroactively even though it held a defendant liable for abating a present polluting condition caused by his discharge of hazardous materials several years before the enactment of the statute. ${ }^{44}$ The court relied upon a line of Supreme Court cases holding that "[a] statute is not rendered retroactive merely because the facts or requisites upon which its subsequent action depends, or some of them, are drawn from a time antecedent to the enactment." ${ }^{45}$ Similarly, in United States $v$. Price, ${ }^{46}$ the court held that former dump owners who had sold their dump before the enactment of RCRA could be held liable under that statute without retroactive application, because the current hazardous condition was caused primarily by the actions and inactions of these defendants. ${ }^{47}$

Unlike in the Diamond Shamrock and Price cases, however, in which it was clear that the defendant's past actions were the actual cause of the improper disposal and the resulting condition to which RCRA was applied, in off-site cases such as the Chemco hypothetical, a third party was the direct cause of the improper disposal. Under 1974 law, the Chemco-like generator/defendant was not connected in any factual or legal way to the improper disposal resulting from the third party's actions. In the RCRA cases, the defendants would have been considered the cause of the improper disposal under then-existing common law causation principles; RCRA's application did not change the status of their actions. By contrast, under 1974 law, Chemco would not have

4022 F. Cas. at 767.

4142 U.S.C. $\$ \S 6901-6987$ (1976 \& Supp. IV 1980).

42 See, e.g., United States v. Diamond Shamrock Corp., 12 ENVTL. L. REP. (ENvTL. L. INsr.) 20,819 (N.D. Ohio 1981); United States v. Price, 523 F. Supp. 1055 (D.N.J. 1981).

4312 ENVTL. L. ReP. (ENVIL. L. INST.) 20819 (N.D. Ohio 1981).

44 Id.

45 Reynolds v. United States, 292 U.S. 443, 449 (1934) (citation omitted).

46523 F. Supp. 1055 (D.N.J. 1981).

47 Id. 1070-72. 
been deemed the cause of the improper disposal. Only the application of a new law, such as Superfund, can change the status of Chemco's 1974 actions to impute a causal connection to the improper disposal. A law so applied does more than "relate to or draw upon antecedent events"; 48 it attaches a completely new legal significance to those events, and therefore is considered a retroactive law. As the Supreme Court has stated, an act is retroactive in its application if it "assign[s] . . a quality or effect to acts or conduct which they did not have or did not contemplate when they were performed." "49 Because the application of Superfund assigns a new causal quality to Chemco's 1974 actions, such application clearly is a retroactive application.

\section{Did Congress Authorize Retroactive Application of the Superfund Act?}

Retroactive application of Superfund is necessary to hold Chemco-like generators liable for clean-up costs; but is such an application impermissible? Before arguing that retroactive application of the Act is unconstitutional generators such as Chemco might first argue that Congress did not intend to authorize retroactive application. Courts would therefore need to examine the statute and its legislative history carefully in light of relevant rules of construction.

\section{The Presumption Against Retroactive Construction of Statutes}

The Supreme Court has established a strong presumption against retroactive construction of statutes, yet it is not clear exactly how strong that presumption is. In United States v. Heth,,00 the Court first stated that "[w]ords in a statute ought not to have a retrospective operation, unless they are so clear, strong, and imperative, that no other meaning can be annexed to them, or unless the intention of the legislature cannot otherwise be satisfied." 51 Later in the same opinion, the Court seemed to strengthen even further the presumption against retroactive construction by stating that it is not permissible unless such be the "unequivocal and inflexible import of the terms, and the manifest intention of the legislature." ${ }^{52}$ Although the modern Court has most recently

48 Reynolds, 292 U.S. at 449.

49 Union Pacific R.R. v. Laramie Stock Yards, 231 U.S. 190, 199 (1913).

507 U.S. ( 3 Cranch) 399 (1806).

51 Id. 413 (emphasis added).

52 Id. (emphasis added). 
quoted the latter Heth language, ${ }^{53}$ implying that either ambiguous statutory language regarding retroactivity by itself or an unclear legislative intention by itself would be enough to preclude retroactive construction, in practice the courts have treated retroactivity primarily as a question of legislative intention. ${ }^{54}$ It seems, then, that retroactive construction is permissible if the statute offers some support for such construction and the legislative history overwhelmingly supports such construction. If there is ambiguity in the statutory language, however, and any ambiguity at all in the legislative history, then retroactive construction is not permissible even if on balance it appears it was intended.

\section{The Language of Superfund's Liability Provision}

The language of Superfund's liability provision ${ }^{55}$ indicates that it applies retroactively. The critical operative terms of the

53 Greene v. United States, 376 U.S. 149, 160 (1963).

54 See, e.g., United States v. Magnolia Petroleum Co., 276 U.S. 160, 162-63 (1928) ("Statutes are not to be given retroactive effect ... . unless the legislative purpose so to do plainly appears"); United States v. St. Louis, S.F. \& T. Ry. Co., 270 U.S. I, 3 (1926) (language of statutory section, entire act, and legislative history examined before Court reached conclusion that the act should not apply retroactively); United States v. Richardson, 512 F.2d 105, 106 (3d Cir. 1975) ("The question [whether a new Selective Service Act statute of limitation applies retroactively] is one of ascertaining congressional intent"); Hiatt v. Hilliard, 180 F.2d 453, 455 (5th Cir. 1950) ("Whether a statute operates retroactively or prospectively is [a question] of legislative intent"); Silurian Oil Co. v. Essley, 54 F.2d 43, 47 (10th Cir. 1931) ("While the rule is abundantly settled that statutes will not be construed as operating retrospectively unless the legislative intent is unmistakable, .... it is after all a question of legislative intent." Statute held to operate retroactively despite absence of explicit language to that effect); Lamb $v$. Powder River Live Stock Co., 132 F. 434, 436 (8th Cir. 1904) ("The rule that statutes are to be given a prospective, rather than a retrospective, operation, is well recognized; but, like other rules of interpretation, it is resorted to to give effect to the presumed and reasonably probable intention of the Legislature, when the terms of the statute do not of themselves make the intention certain or clear . . . " Statute held to apply retroactively based on congressional intent as revealed by the context of its enactment, but then stricken as violative of the contract clause of the Constitution); Segars v. Gomez, 360 F. Supp. 50, 53 (D.S.C. 1972) ("Of course, whether a statute operates prospectively or retroactively is a matter of legislative intent, and all of the rules [of construction] stated above must bow to any clear statement of Iegislative purpose."); Sovereign Camp, W.O.W. v. Casados, 21 F. Supp. 989, 1000 (D.N.M. 1938) (retroactivity a question of legislative intent, which, if not otherwise expressed, will be determined from entire act and legislative history; act here construed may be applied retroactively). But see In re Surface Mining Regulation Litig., 452 F. Supp. 327, 339 (D.D.C. 1978), aff'd in part, rev'd in part, 627 F.2d 1346 (D.C. Cir. 1980) ("II]n order for a provision to have a retrospective application, the requirement must be explicitly and unmistakably set forth in the statute.").

5542 U.S.C. $\$ 9607$ (a) (Supp. IV 1980). The section reads as follows:

a) Notwithstanding any other provision or xule of law, and subject only

to the defenses set forth in subsection (b) of this section- 
section are written in the past tense, which has been held to be strong evidence that retroactive application was intended. ${ }^{56}$ Section 107(a)(2) holds liable "any person who at the time of disposal of any hazardous substance owned or operated any facility at which such hazardous substances were disposed of." This language clearly reflects an intent on the part of Congress to impose liability retroactively. ${ }^{57}$ Section $107(a)(3)$, which applies to hazardous waste generators, holds liable for response costs "any person who by contract, agreement, or otherwise arranged for disposal or treatment, or arranged with a transporter for transport for disposal or treatment, of hazardous substances" 58 that even-

(3) any person who by contract, agreement, or otherwise arranged for disposal or treatment, or arranged with a transporter for transport for disposal or treatment, of hazardous substances owned or possessed by such person, by any other party or entity, at any facility owned or operated by another party or entity and containing such hazardous substances ...

(4) ... shall be liable for-

(A) all costs of removal or remedial action incurred by the United States Government or a State not inconsistent with the national contingency plan;

(B) any other necessary costs of response incurred by any other person consistent with the national contingency plan; and

(C) damages for injury to, destruction of, or loss of natural resources, including the reasonable costs of assessing such injury, destruction, or loss resulting from such release.

(Emphasis added).

56 It is a well-established principle of statutory construction that the words of statutes should be interpreted if possible in their "ordinary everyday sense" and that departure from a literal reading is justified only if such reading would lead to absurd, unreasonable, or clearly unintended results. See, e.g., Malat v. Riddell, 383 U.S. 569, 571-72 (1966); Richards v. United States, 369 U.S. 1, 9 (1962); United States v. American Trucking Ass'ns. Inc., 310 U.S. 534,543 (1940). Hence, if Congress uses the past tense in a statute, it should read, ordinarily, as applying to past events. In several cases Congress's use of the past tense (or present perfect tense) in key operative terms was critical to the Court's holding that the statute applied retroactively. See, e.g., Barrett v. United States, 423 U.S. 212, 216-17 (1976) (use of present perfect tense, denoting an act that has already been completed, indicates that the Act can be applied even of the requisite events occurred in the past); Eichenlaub v. Shaughnessy, 338 U.S. 521, 527-30 (1950), discussed in Costello v. Immigration Service, 376 U.S. 120, 123 (1964) (Eichenlaub Court "was aided considerably in its search for the proper construction of the statute by Congress' use of the past tense in the phrase "have been or may hereafter be" ").

Strictly literal interpretation does present some problems, however. In Scarborough v. United States, 431 U.S. 563, 569-71 (1977), the Court cautioned that although Congress often skillfully chooses the tense of words in a statute, in some cases the statute was hastily enacted and the precise choice of words may have been unintentional, making further inquiry into congressional intent necessary. See infra text accompanying notes $62-78$ for such further inquiry into the history of Superfund's enactment.

5742 U.S.C. $\$ 9607$ (a)(2) (Supp. IV 1980) (emphasis added).

58 Id. $\$ 9607$ (a)(3) (emphasis added). 
tually create a condition the government deems hazardous and cleans up under the national contingency plan. The past tense word "arranged" is used twice, indicating that the Act can be applied to pre-enactment generators.

The statute provides further, although less direct, indication that the liability provisions were meant to apply retroactively. Section 107(f) specifically exempts generators and others from liability for damages to natural resources if "such damages and the release of a hazardous substance from which such damages resulted have occurred wholly before the enactment of this Act." 59 Section $111(d)(1)$ then reiterates the exclusion of liability for preenactment natural resource damage by stating: "No money in the Fund may be used . . . where the injury, destruction, or loss of natural resources and the release of a hazardous substance from which such damages resulted have occurred wholly before the enactment of this Act." 60 The Superfund Act clearly excludes from its coverage pre-enactment natural resource damage; significantly, however, there is no similar language in the statute exempting pre-enactment generators from liability for damages other than those to natural resources. The unambiguous statutory exemption for pre-enactment natural resource damage contrasts sharply with the waste-damage liability provision, creating the implication that Superfund does apply retroactively to impose liability upon preenactment generators, but only for clean-up costs for wastes, not for natural resources damages such wastes caused.

It is easy to argue, of course, that if retroactive effect were intended, Congress could have simply inserted a clause clearly stating that the liability provisions were to apply to pre-enactment waste generators. The noticeable absence of such a clause may create enough ambiguity to require an examination of the' Act's legislative history to determine if Congress displayed a clear intention to permit retroactive construction. ${ }^{61}$

50 Id. $\$ 9607$ (f).

${ }^{\circ 0} I d . \$ 9611(\mathrm{~d})(1)$.

${ }^{61}$ An additional argument can be made against retroactive application of the liability provisions. Although $\S 107(a)$ applies to those who "arranged" for disposal, it states that such parties "shall be" liable for the clean-up costs. See 42 U.S.C. $\$ 9607$ (Supp. IV 1980). Normally, the use of the word "shall" connotes prospective operation. Summers v. Skibs A/S Myken, 191 F. Supp. 929, 930 (E.D. Pa. 1961), quoting Terracciana v. Magee, 53 N.J. Super. 557, 566, 148 A.2d 68, 74 (1959) ("As an aid in interpretation of statutes it is a cardinal rule that the word 'shall' connotes prospective operation and cannot embrace events which have already occurred"); Weiler v. Dry Dock Sav. Inst., 258 A.D. 581, 583, 17 N.Y.S.2d 192, 194 (1940), aff'd 284 N.Y. 630,29 N.E.2d 938, 19 N.Y.S.2d 145 (1940). 


\section{Superfund's Legislative History Strongly Supports Retroactive Application}

The Superfund Act as finally enacted was the product of a last-minute Senate compromise. Some of its final language was taken from the House-passed version, ${ }^{62}$ some from the Senate committee bill, ${ }^{63}$ and some was conceived anew by an ad hoc committee of Senators who fashioned the last-minute compromise ${ }^{64}$ which eventually became the final version. Debate on the final language was quite limited, ${ }^{65}$ and because the House approved the Senate compromise version without change, ${ }^{66}$ a House-Senate conference was not necessary and thus there is no potentially clarifying conference report. Ascertaining "congressional intent" from such a patchwork bill is a complex, if not impossible task. It appears, however, that Congress's intent with respect to retroactive application of the Act never changed throughout the several stages of congressional consideration. ${ }^{67}$ Thus, congressional intent regarding

This argument, however, is not persuasive. The use of "shall be" rather than "are" simply reflects the fact that liability does not attach until a court finds a party liable. The use of the word "arranged" indicates that although the conduct which gives rise to liability could have occurred prior to the enactment of Superfund, such conduct will result in liability.

62 H.R. 7020, 96th Cong., 2d Sess. (1980).

63 S. 1480, 96th Cong., 2 d Sess., 126 Cong. Rec. S14,938-48 (daily ed. Nov. 24, 1980) [hereinafter cited as Senate committee version].

${ }^{64}$ S. 1480, 96th Cong., 2d Sess., 126 Cong. Rec. S14,840-53 (daily ed. Nov. 21,1980 ) [hereinafter cited as Senate compromise version]. The bill's passage is noted at 126 Cong. REc. S15,009 (daily ed. Nov. 24, 1980).

65 See 126 Cong. REc. S14,962-15,009 (daily ed. Nov. 24, 1980); 126 Cong. REC. H11,786-802 (daily ed. Dec. 3, 1980).

66126 Cong. REC. H11,802 (daily ed. Dec. 3, 1980).

67 The House committee's version of Superfund, H.R. 7020, 96th Cong., 2d Sess., reprinted in H.R. REP. No. 1016, supra note 8, at 2-17 [hereinafter cited as House committee version] (liability section reprinted in 126 CoNG. Rec. H9459 (daily ed. Sept. 23, 1980)) was amended on the House floor on September 23, 1980. 126 Cong. REC. 9461, 9468 (daily ed. Sept. 23, 1980). But the floor amendments did not change the committee language with regard to the retroactivity of the liability provisions. Compare House committee version $\$ 3071$, H.R. REP. No. 1016, supra note 8, at 14-15, 126 CoNG. REc. at H9459, with $\$ 3071$ as amended and passed by the House on September 23, 1980, 126 Cong. Rec. at 9461, 9468 [hereinafter cited as House-passed version]. The past tense words "caused" and "contributed" are used in both versions. Hence both the House committee report, H.R. Rep. No. 1016, supra note 8, at 33-35, and House floor debate on the original version, 126 CoNG. Rec. at $9461-68$, may be consulted.

The Senate committee version of Superfund, S. 1480 , see supra note 63 , was quite different from the House versions with regard to the extent of generator liability, but was not different in any way that would have affected its retroactivity: All three versions used past tense words at the critical times. Compare House committee version, supra, $\$ 3071$ with Senate committee version, supra note $63, \$ 4$, and with House-passed version, supra, \$3071. Finally, the "compromise bill," supra note 64 , passed by the Senate to replace the two House versions and the Senate committee version, used the same past tense words found in the Senate 
the Act's retroactivity can be gleaned from early. committee reports as well as from later floor debates.

The legislative history of the Superfund Act clearly indicates that Congress intended the clean-up liability provisions to apply retroactively. Both the House and the Senate committee reports described, as a primary goal of Superfund, the need to remedy the effects of inadequate past disposal practices. ${ }^{68}$ Both reports described as targets of the legislation several inactive sites, the clean-up of which would require retroactive application of the Act. ${ }^{\text {eg }}$

In discussing the need for new legislation, the House report noted the failure of the Resource Conservation and Recovery Act ${ }^{70}$ to address the consequences of inactive hazardous waste sites:

The [RCRA] is prospective and applies to past sites only to the extent that they are posing an imminent hazard. ...

It is the intent of the Committee in this legislation to initiate and establish a comprehensive response and financing mechanism to abate and control the vast problems associated with abandoned and inactive hazardous waste disposal sites. ${ }^{71}$

In addition, the Senate report specifically discussed the statutory language that ultimately became section 107(f), which creates an explicit exception to retroactive application of the liability provisions with regard to damages to natural resources. ${ }^{72}$ The

committee version, indicating that there was no change regarding the retroactivity issue, and that the Senate committee report, S. REP. No. 848, supra note 15 , may also be consulted. Because the House adopted the Senate compromise version without change, the House and Senate debates on that version are also instructive. See 126 Cong. Rec. S14,962-15,009 (daily ed. Nov. 24, 1980); 126 Cong. Rec. H11,787-802 (daily ed. Dec. 3, 1980). Simply stated, both the House and the Senate used language indicating retroactive application in all versions of Superfund considered, and it is therefore appropriate to look to all documents making up the legislative history for elaboration on this point.

68 S. REP. No. 848 , supra note 15 , at 12 ; H.R. REP. No. 1016, supra note 8 , at 17, reprinted in 1980 U.S. CoDE CONG. \& AD. NEws at 6120.

${ }^{69}$ S. Rep. No. 848, supra note 15, at 9-10; H.R. ReP. No. 1016, supra note $S$, at 18-20, reprinted in 1980 U.S. CoDE CoNg. \& AD. NEws at 6120-23.

7042 U.S.C. $\$ \$ 6901-6987$ (1976 \& Supp. III 1979).

71 H.R. REP. No. 1016, supra note 8 , at 22 , reprinted in 1980 U.S. CODE CoNG. \& AD. NEws at 6125 .

72 S. Rep. No. 848 , supra note 15 , at 37 . The report provides that neither the liability scheme ... nor the Fund can be used to recover for natural resource and property damages when the damages and the release 
report made it clear that this limitation was only an exception, stating that "[c]osts of removal (clean-up and containment) are not affected by this provision." 73 This clearly implies that retroactive application of the liability provisions pertaining to clean-up costs was intended.

The very fact that several opponents of Superfund protested the unfairness of retroactive application of the Act is an indication that the Act was generally understood to permit such application. Concern about the fairness of retroactive imposition of liability was expressed at numerous times during congressional consideration of the legislation-first by three Senators filing "Additional Views" to the committee report, ${ }^{74}$ and later by several Representatives on the floor of the House during its initial consideration of the Act. ${ }^{75}$ During the full Senate's consideration of the legislation, several Senators, including the bill's primary sponsor, remarked that clean-up of inactive sites was imperative, and used as examples waste sites which could not have their clean-up financed by Superfund's liability provisions unless the Act was applied retroactively. ${ }^{76}$

Although the above sketch of Superfund's legislative history provides fairly strong evidence of Congress's intent to authorize retroactive application of the liability provisions, at no point did any supporter of the legislation explicitly state such an intention. The applicable statutory construction standard does not require an explicit statement; the legislative history need only offer strong support for a retroactive construction. ${ }^{77}$ In light of the accusations from Superfund opponents that retroactive application of the liability provisions would be unfair, it is understandable that, as a matter of strategy, the legislation's supporters would not call attention to their desire to permit retroactive application, but would instead claim that the Act does little more than codify pre-

of hazardous substances causing such damages occurred prior to enactment of [the Act]. This provision allows for recovery only of prospective natural resource and property damages.

$73 \mathrm{Id}$.

${ }_{74} \mathrm{Id}$. 119-22 (views of Sens. Domenici, Bentsen, and Baker).

75126 Cong. Rec. H9446-48; 9465-68 (daily ed. Sept. 23, 1980).

76 See, e.g., 126 Conc. REc. S14,963 (daily ed. Nov. 24, 1980) (remarks of Sen. Randolph, primary Senate sponsor) (procedures are needed to deal with past disposal of chemical wastes; numerous abandoned sites listed); id. S14,969 (remarks of Sen. Moynihan) (Superfund needed to clean up Love Canal, a disaster caused by 30 years of improper disposal); id. S14,97I (remarks of Sen. Bradley) (approximately 235 abandoned or inactive hazardous waste sites in New Jersey alone would finally be cleaned up under Superfund).

77 See supra text accompanying notes 50-54. 
existing common law principles governing past disposal procedures. ${ }^{78}$

\section{Conclusion: The Act Permits Retroactive Application}

The courts interpreting Superfund should hold that the language of the liability provisions, read in light of the legislative history, shows sufficient congressional intent to permit retroactive application under even the stringent standard applicable. Chemco or similar generators claiming that the statute should not be construed as permitting retroactive application could succeed only by convincing a court to apply an even stronger presumption against retroactive construction than that which has been described.

One line of Supreme Court cases has held that a construction that raises a serious constitutional difficulty should be avoided in favor of a feasible alternative construction that does not. ${ }^{78}$ Thus, if Chemco can demonstrate that retroactive application of Superfund to its 1974 activities raises a serious question of constitutionality, a court might hold that the minor ambiguities in the statutory language preclude retroactive application as a matter of statutory construction. For example, in 1977 the New Jersey Superior Court held that because of possible constitutional difficulties, the New Jersey Spill Compensation and Control Act ${ }^{80}$ should not be construed as applying retroactively to formerly innocent parties. ${ }^{81}$

Alternatively, Chemco might try to convince a court that even if it determines that Congress intended to authorize retroactive construction, the liability provisions should be stricken on constitutional grounds.

Both of these arguments depend upon the strength of the claim that retroactive application of Superfund is unconstitutional.

78 Representative Gore made this claim, arguing that if common law strict liability doctrines had been properly applied, past generators would have been strictly and vicariously liable for all damages resulting from their wastes. See 126 Conc. Rec. H9462 (daily ed. Sept. 23, 1980). Also, in a letter to the Senate Committee on Environment and Public Works, Douglas M. Costle, then the Administrator of the E.P.A., claimed that Superfund did nothing more than expand slightly on existing common law. The committee report included Costle's letter as a supplement. See S. Rep. No. 848, supra note 15, at 97-100.

79 See, e.g., Anniston Mfg. Co. v. Davis, 301 U.S. 337, 351-52 (1937); Crowell v. Benson, 285 U.S. 22, 62 (1932); In re Moneys Deposited, Etc., 243 F.2d 443; 448 (3d Cir. 1957). See also cases cited in United States v. Lindsay, 346 U.S. $568,571 \mathrm{n} .2$ (1954) (statutes construed to avoid inequitable and unfair results of retroactive application).

80 N.J. StaT. AnN. 58:10-23.11 (West 1982).

81 State Dept. of Envtl. Protection v. Exxon Corp., 151 N.J. Super. 464, 376 A.2d 1339 (1977). 


\section{Is Retroactive Application of Superfund Unconstitutional?}

Far from raising constitutional questions serious enough to preclude retroactive construction of the Superfund Act or to invalidate the liability provisions, the statute is well within due process ${ }^{82}$ and other constitutional boundaries. ${ }^{83}$

\section{Superfund is not an Ex Post Facto Law}

It should be clear that the Constitution's explicit prohibition against ex post facto lawmaking ${ }^{84}$ applies only to criminal laws that inflict punishment. ${ }^{85}$ Superfund's liability provisions contain no criminal penalties; pre-enactment violators are not even subject to civil penalties if they cooperate with government clean-up efforts ${ }^{86}$-they are merely required to reimburse the government for the cost of waste site clean-up. ${ }^{87}$

As the Chemical Manufacturers' Association suggested in preSuperfund hearings, ${ }^{88}$ however, generators such as Chemco might argue nonetheless that imposition of what may be heavy costs through joint and several liability ${ }^{89}$ is in effect punishment of a formerly innocent generator. ${ }^{90}$ Usery $v$. Turner Elkhorn Mining $C_{0 .}{ }^{91}$ indicates that the Supreme Court would hesitate to approve the retroactive imposition of liability on any theory of "blameworthiness." 92 Pointing to the language in the legislative history condemning the chemical industry, Chemco could argue that Congress intended to "blame" past hazardous waste generators for

82 See infra text accompanying notes 94-107.

83 See infra text accompanying notes 84-93.

84 U.S. Const. art. I, $\$ 9$, cl. 3.

85 United States Trust Co. of New York v. New Jersey, 431 U.S. 1, 17 n.13 (1977).

86 If they fail to cooperate with government clean-up efforts, they may be subject to civil penalties under 42 U.S.C. $\$ 9606$ (b) (Supp. IV 1980).

87 See supra text accompanying notes 55-60.

88 See supra note 28 and accompanying text.

89 See infra text accompanying notes $180-240$ for an assessment of when joint and several liability is in fact appropriate under the Act.

90 The Supreme Court has held that penalties that are not technically criminal may nevertheless be classified as such in certain circumstances. In Burgess $v$. Salmon the Court held that a statute permitting collection of past tax penalties that the government had failed to collect was an ex post facto law, stating that "the ex post facto effect of a law cannot be evaded by giving a civil form to that which is essentially criminal." 97 U.S. 381, 385 (1878) (citations omitted). In Lehman v. Carson, Justice Black argued in a concurring opinion that a retroactive law requiring deportation of aliens for past offenses inflicted a punishment and was in fact an ex post facto law. 353 U.S. 685, 690-91 (1957) (Black, J., concurring).

91428 U.S. 1 (1976).

92 Id. $17-18$ (citations omitted). 
present problems. This argument, however, is quite tenuous. The imposition of clean-up liability on past chemical waste generators, without any accompanying penalties for bad behavior, is based on the types of policies animating strict tort liability, ${ }^{93}$ not on any theory of blameworthiness.

In sum, the argument characterizing Superfund's liability provisions as ex post facto lawmaking should not succeed.

\section{Retroactive Application of Superfund Does Not Violate Due Process}

Unlike ex post facto criminal legislation, retroactive civil legislation is not expressly prohibited by the Constitution. It is well established that mere retroactive application does not render a civil statute unconstitutional. ${ }^{94}$ Such a law is not invalid unless it violates a constitutional provision such as the due process clause, the equal protection clause, or the clause forbidding impairment of contractual obligations. ${ }^{95}$ Of these, the only viable argument for a generator such as Chemco is that retroactive imposition of liability is a violation of the due process clause. This contention, however, is without real merit.

Chemco would argue that it is unfair to impose an unexpected and substantial cost on chemical companies that were not negligent under prior law, having complied with prior law in good faith. It could stress that it had relied on 1974 laws and requirements in making waste disposal plans, and had structured its insurance coverage based on potential liability under prior law. Chemco would contend that Superfund's imposition of liability for these actions is so unfair that it violates substantive due process requirements.

This argument lacks precedential support; no federal court has ever issued such a holding. In fact, the only decision offering any support for such a contention is State Department of Environmental Protection v. Exxon Corp.,96 in which a New Jersey court held that constitutional difficulties precluded retroactive applica-

${ }^{93}$ See 126 Cong. Rec. H9463 (daily ed. Sept. 23, 1980) (remarks of Rep. Gore) (liability provisions patterned after common law strict liability for ultrahazardous activity); S. REP. No. 848, supra note 15, at 13 (strict liability is foundation of S. 1480).

94 Cohen v. Beneficial Indus. Loan Corp., 337 U.S. 541, 554 (1949); Blount v. Windley, 95 U.S. 173, 180 (1877).

95 The contract clause argument is, however, often subsumed in the due process argument. See Nachman Corp. v. Pension Benefit Guar. Corp., 592 F.2d 947, 959 (7th Cir. 1979).

98 151 N.J. Super. 464, 376 A.2d 1339 (1977). 
tion of the New Jersey Spill Compensation and Control Act ${ }^{97}$ because such an application would "place the enormous burden of abating a condition created by a third party on the shoulders of a party innocent of any wrongdoing." 98 The only support offered by any federal body consists of comments made by Congressmen during consideration of the Superfund Act, ${ }^{99}$ including the suggestion made by three Senators filing "Additional Views" to the Senate committee report that retroactive application of the Act would not be "consistent with American Standards or [sic] jurisprudence" and "may be unconstitutional." 100

Until relatively recently, the Supreme Court had not formulated any explicit tests to aid in the determination whether retroactive application of a law was reasonable or fair under the due process clause, but several commentators have summarized the factors that the Court seems to have considered.101 The Court has usually weighed the nature and strength of the public interest served by the statute and the method used to further that interest against the extent to which the new law has modified prior rights and duties, the nature of the rights and duties affected, and the extent to which the parties involved relied upon prior law. ${ }^{102}$

The Court's recent decision in Usery v. Turner Elkhorn Mining Co., ${ }^{103}$ however, contains a direct and explicit consideration of the claim that retroactive application of a law violates the due process clause. In Turner Elkhorn Mining, the Court upheld the constitutionality of a black lung benefit statute which imposed liability retroactively upon mine operators whose former employees had been disabled by black lung disease well before the enactment of the statute. The Court there held: "[O]ur cases are clear that legislation readjusting rights and burdens is not unlawful solely because it upsets otherwise settled expectations .... This

97 N.J. Stat. ANN. 58:10-23.11 (West 1982).

98151 N.J. Super. at 482,376 A.2d at 1348. Of course, dictum from a New Jersey court construing a New Jersey statute under New Jersey statutory construction principles is of little, if any, precedential value to a generator trying to prove that a federal law is unconstitutional.

90 See supra notes 29-31.

100 S. REp. No. 848, supra note 15 , at 120 (views of Senators Domenici, Bentsen, and Baker).

101 See, e.g., Hochman, The Supreme Court and the Constitutionality of Retroactive Legislation, 73 HARv. L. REv. 692 (1960); Slawson, Constitutional and Legislative Considerations in Retroactive Lawmaking, 48 CALIF. L. REv. 216 (1960); see also Greenblatt, Judicial Limitations on Retroactive Civil Legislation, 51 Nw. U.L. REv. 540 (1956).

102 Hochman, supra note 101, at 697.

103428 U.S. 1 (1976). 
is true even though the effect of the legislation is to impose a new duty or liability based on past acts." 104 A constitutional attack on retroactive legislation based on the due process clause, like all substantive due process claims in the economic field, imposes a heavy burden on the one complaining of the violation:

It is by now well established that legislative Acts adjusting the burdens and benefits of economic life come to the Court with a presumption of constitutionality, and that the burden is on one complaining of a due process violation to establish that the legislature has acted in an arbitrary and irrational way. ${ }^{105}$

A Chemco-like generator faces difficulty in showing that the Superfund Act's liability provisions are an "arbitrary and irrational" way of approaching the hazardous waste problem. The mine operators in Turner Elkhorn Mining argued that the Black Lung Act spread costs in an "arbitrary and irrational" manner because it imposed proportionally heavier costs on operators whose former employees had contracted black lung disease, instead of simply taxing all coal miners presently in business based on their present employment patterns. They noted that an operator whose work force had declined would incur a liability that was disproportionately high compared to the present size of his operation, and argued that such imposition of liability for past events would give a competitive advantage to new entrants into the industry, while competitive factors would prevent the older companies from passing on to the consumer the costs of their newly imposed liability. ${ }^{106}$ Chemco could make a similar contention, arguing that a third party's negligence should not result in disproportionate liability on past generators who had obeyed all prior disposal laws, and that such retrospective imposition of liability will make such generators less competitive today despite the fact that they always used legal disposal procedures, and may now be using the safest possible disposal methods.

The Supreme Court rejected this line of argument in the Turner Elkhorn Mining case, stating that

104 Id. 16 (citations omitted).

105 Id. 15 (citing Ferguson v. Skrupa, 372 U.S. 726 (1963)) (emphasis added). See Williamson v. Lee Optical Co., 348 U.S. 483, 487-88 (1955). See also Pension Benefit Guar. Corp. v. Ouimet Corp., 630 F.2d 4 (Ist Cir. 1980) (retroactive application of the Employee Retirement Income Security Act passes rationality test).

108428 U.S. at 18. 
it is for Congress to choose between imposing the burden ... on all operators ... or ... [imposing] that liability solely on those early operators. ... We are unwilling to assess the wisdom of Congress' chosen scheme by examining the degree to which ... retrospective liability imposed on the early operators can now be passed on to the consumer. It is enough to say that the Act approaches the problem of cost spreading rationally; whether a broader cost-spreading scheme would have been wiser or more practical under the circumstances is not a question of constitutional dimension. ${ }^{107}$

It seems clear that the cost-spreading scheme imposed by Superfund meets this minimum rationality standard, especially because the concepts underlying generator liability are quite similar to well-accepted strict liability tort principles. In fact, imposing liability for dumpsite clean-up on past waste generators, who have at least a common-sense connection-if not a previously recognized legal connection-to the problem, may be more rational than holding all chemical companies or the general public responsible for clean-up through an across-the-board tax scheme: such parties may have no connection whatsoever to the condition.

Given the minimum rationality test the Court has now articulated for due process attacks on retroactive legislation, a Chemcolike constitutional claim is without merit, and Superfund's liability provisions, as has been demonstrated, therefore may be applied retroactively.

\section{The Scope and Meaning of Superfund's Third-Party "Due Care" Defense to Liability \\ A. Liability of Pre-enactment Generators}

Although Superfund's liability provisions constitutionally may be applied to past hazardous waste generators, the precise standard of liability imposed by the Act is not readily apparent. The Act holds past waste generators "liable" for clean-up costs, ${ }^{108}$ but provides several statutory defenses to liability, the most significant being a "due care" defense open to generators who can establish that certain third parties improperly disposed of their wastes. ${ }^{109}$

107 Id. 18-19.

10842 U.S.C. $\$ 9607$ (a) (Supp. IV 1980).

$109 \mathrm{Id}$. $\$ 9607$ (b)(3). The other two statutory defenses are that the release was caused solely by an act of God or an act of war. Section 9607 (b), which contains all of the Act's statutory defenses, reads as follows: 
At least two sources of confusion obfuscate the intended meaning of the liability scheme ${ }^{110}$ established by the Act; both result from final language that was the product of a last-minute compromise involving poorly drafted and poorly explained changes in the liability and statutory defense sections. ${ }^{111}$ The first problem is Congress's meaning in using the word "liable" in the final version; earlier versions had held generators and others "strictly liable." The second difficulty lies in determining when Congress intended the third party "due care" defense to be available, and in ascertaining what behavior constitutes "due care."

This Comment asserts that Superfund imposes "strict liability" upon all defendants unless they can utilize one of the statutory defenses provided. Further, it argues that the "due care" defense should be available to all past (pre-enactment) generators who can show that their wastes were improperly disposed of by a third party, even if that party was contractually related to the generator. That defense, however, should not be available to future (post-enactment) generators unless they can establish that the third party who caused the improper release was wholly unrelated. Finally, this section

(b) There shall be no liability under subsection (a) of this section for a person otherwise liable who can establish by a preponderance of the evidence that the release or threat of release of a hazardous substance and the damages resulting therefrom were caused solely by-

(1) an act of God;

(2) an act of war;

(3) an act or omission of a third party other than an employee or agent of the defendant, or than one whose act or omission occurs in connection with a contractual relationship, existing directly or indirectly with the defendant (except where the sole contractual arrangement arises from a published tariff and acceptance for carriage by a common carrier by rail), if the defendant establishes by a preponderance of the evidence that (a) he exercised due care with respect to the hazardous substance concerned, taking into consideration the characteristics of such hazardous substance, in light of all relevant facts and circumstances, and (b) he took precautions against foreseeable acts or omissions of any such third party and the consequences that could foreseeably result from such acts or omissions; or

(4) any combination of the foregoing paragraphs.

110 The "liability scheme" includes the underlying liability standard set by $\$ 9607$ (a) and the statutory defenses established by $\$ 9607$ (b). Obviously, the two sections are interrelated closely.

111 See supra text accompanying notes 62-66. Several representatives complained about the limited time the House had to consider the Senate-passed compromise bill, noting that there were several ambiguities in the final language that needed further refinement. See, e.g., 126 Cong. REc. H11,790-91 (daily ed. Dec. 3, 1980) (remarks of Reps. Broyhill and Harsha); id. H11,795 (remarks of Rep. Biaggi). Nevertheless, the House passed the Senate compromise bill without change, eliminating the need for a potentially clarifying conference report. Id. Hil,803. 
offers illustrations of behavior that should allow a generator to successfully invoke the "due care" defense.

\section{B. The Legislative History of the Liability Provisions}

Because the Superfund Act does not require the promulgation of any regulations to clarify the liability provisions, ${ }^{112}$ and because the courts have not yet provided an exhaustive interpretive holding, the statute and accompanying legislative history furnish the only meaningful sources for exposition. During this examination, it is critical to trace the changes that occurred in the liability language as the Act made its way through the congressional maze. An examination of those changes and the probable reasons for them sheds some light on the nature and meaning of the final compromise agreement which became the Act.

Four versions of Superfund must be analyzed to understand properly the meaning of the final version: (1) the House bill as reported by the House Commitee on Interstate and Foreign Commerce; ${ }^{113}$ (2) the bill that initially passed the House; ${ }^{114}$ (3) the Senate bill as reported by the Senate Committee on Environment and Public Works, ${ }^{115}$ and (4) the Senate compromise bill, ${ }^{116}$ which was eventually adopted by both the Senate and the House and became the Act. Of the four versions, the House committee bill contained the weakest liability provisions, and the Senate committee bill contained the strongest. A court attempting to discern where the final version should be placed on the liability spectrum should begin by analyzing the House committee bill.

\section{The House Committee Bill}

Although the House committee bill as reported used the term "strictly liable" in its liability provision, ${ }^{117}$ it did not in fact hold

112 See 42 U.S.C. $\$ 9607$ (Supp. IV 1980).

113 H.R. 7020, 96th Cong., 2d Sess., reprinted in H.R. ReP. No. 1016, supra note 8, at 2-17 [hereinafter cited as the House committee bill].

114 H.R. 7020, 96th Cong., 2d Sess., 126 Conc. Rec. H9479 (daily ed. Sept. 23, 1980) [hereinafter cited as the House-passed bill]. The full text of the Housepassed bill was not reprinted in the Record.

115 S. 1480, 96th Cong., 2d Sess., 126 Cong. Rec. S14,938-48 (daily ed. Nov. 24, 1980 [hereinafter cited as the Senate committee bill].

116 H.R. 7020, 96th Cong., 2d Sess., 126 Cong. Rec. S14,988-15,002, 15009 (daily ed. Nov. 24, 1980) [hereinafter cited as the Senate compromise bill]. The Senate compromise passed the House unchanged, 126 CoNG. REC. H11,803 (daily ed. Dec. 3, 1980), and thus became the Act. Because all revenue raising bills must originate in the House, the Senate was required to retain the House bill number, but it struck all of the House-passed language after the enacting clause and substituted the Senate compromise language. H9459.

117 House committee bill, supra note $113, \S 3071(\mathrm{a})(1), 126$ Cong. Rec. at 
all hazardous waste generators, especially those who contracted out their disposal operations, strictly liable for damages caused by their wastes. First, the bill imposed liability only on defendants who "caused or contributed" to an improper release or threatened release of hazardous materials. ${ }^{118}$ As the committee report clearly states, "the mere act of generation . . . of hazardous waste, or the mere existence of a generator's or transporter's waste in a site with respect to which cleanup costs are incurred would not, in and of itself, result in liability under section 3071." 119 This would not be the case if a strict liability standard were intended, and the committee further stated that "the usual common law principles of causation, including those of proximate causation, should govern the determination of whether a defendant 'caused or contributed' to a release or threatened release." 120 Second, the House committee's third party "due care" defense was so broad as to be available to all generators who had contracted out their waste disposal, ${ }^{121}$ a fact lamented by several representatives favoring strict and vicarious liability. ${ }^{122}$ The net effect was a bill that held past and future generators such as Chemco, who contracted for disposal with a third party, only to. a "due care" standard.

\section{The House-passed Version (Gore Amendments)}

When the committee bill's liability provisions reached the House floor, they were criticized as falling far short of strict liability. ${ }^{123}$ A "compromise amendment," described as a middle ground between strict liability and the negligence-like "due care" standard imposed by the House committee bill, was offered by Representative Albert Gore, Jr..$^{124}$ The Gore Amendment did not change the requirement that the defendant must have "caused or contributed" to a release to be held "strictly liable" for clean-up costs, ${ }^{125}$ so, as Representative Madigan made clear, ${ }^{126}$ the com-

118 Id.

119 H.R. REP. No. 1016, supra note 8, at 33, reprinted in 1980 U.S. CODE CoNG. \& AD. NEws at 6136.

120 Id. at 33, reprinted in 1980 U.S. CoDE Cong. \& AD. News at 6136.

121 House committee bill, supra note $113, \S 3071(\mathrm{a})(1)(\mathrm{C}), 126$ CoNG. REc. at $\mathrm{H} 9459$.

122 See, e.g., 126 Conc. REc. H9462-63 (daily ed. Sept. 23, 1980) (remarks of Rep. Gore); id. H9468 (remarks of Rep. Jeffords).

123 See supra note 122 and accompanying text.

124126 Cong. Rec. H9461 (daily ed. Sept. 23, 1980). As discussed infra note 153 and accompanying text, the Gore language was incorporated substantially into the final bill.

125 House-passed bill, supra note 114, $\$ 3071$ (a)(1).

${ }^{126}$ See 126 Cong. Rec. H9465-66 (daily ed. Sept. 23, 1980). 
mittee bill's negligence-like proximate causation principles still applied. The Gore Amendment did, however, limit the availability of the third party "due care" defense to instances in which the defendant can establish that the hazardous release was caused solely by

an act or omission of a third party other than (i) an employee or agent of the defendant, or (ii) a person whose act or omission occurs in connection with a contractual relationship, existing directly or indirectly, with the defendant. ${ }^{127}$

So, in contrast with the committee version, the "due care" defense was not made available to a defendant who could establish that any third party caused the release.

It is unclear, however, whether the Gore Amendment's limitation of the third party "due care" defense was intended to apply retroactively. A quick reading of the amendment's language seems to indicate that the defense would not be available to past generators such as Chemco who contracted with third parties to dispose of hazardous waste, making such generators strictly liable for releases. Although there is support for such a reading, a stronger argument can be made that the limitation was not intended to apply retroactively to prevent past generators who contracted for disposal from utilizing the "due care" defense. That is, the better interpretation of the amendment is that the "due care" defense is unavailable only when the third party involved was an employee or agent of the defendant or a person entering into a future (postenactment) contractual relationship with the defendant. Given the strong presumption against retroactive construction outlined above, ${ }^{128}$ the use of the word "occurs" instead of the past tense word "occurred" 129 indicates that the Gore Amendment's "con-

127 House-passed bill, supra note $114, \S 3071(a)(1)(C), 126$ Cong. REc. at H9461 (emphasis added). The act of God and act of war defenses were also retained, $i d$. $\$ 3071(\mathrm{a})(1)(\mathrm{A})$, as was a later-deleted defense for releases caused solely by government actions. Id. $\$ 3071$ (a)(1)(B), 126 Cong. REC. at 9459.

128 See supra text accompanying notes 50-54.

129 As stated supra note 56, the words of a statute should ordinarily be read literally, and the tense used is one guide to proper construction. In several cases, courts have held that retroactive construction is not appropriate if the key terms of the statute are in the present tense. See, e.g., Driver v. Helms, 577 F.2d 147, 149-50 (1st Cir. 1978) (because operative language of statute is in present tense, application to past actors is not appropriate unless the plain meaning of the language would produce an absurd result, which is not the case here), rev'd on other grounds sub nom. Stafford v. Briggs, 444 U.S. 527 (1980); Reuther v. Trustees of Trucking Emp., 575 F.2d 1074, 1077 (3d Cir. 1978) (although a fortress should 
tractual relationship" limitation on the "due care" defense applies only prospectively to prevent future waste generators from avoiding "strict liability" by contracting out for waste disposal..$^{130}$

The uncertainty regarding the proper interpretation of the Gore Amendment created by the use of the present tense in the amendment's language is exacerbated by the very ambiguous statements made during the House's consideration of the amendment. Representative Gore's own statements provide a prime example. "Prospective only" interpretation is supported by his statements that the purpose of the amendment was to remove "the ability of and incentive for a defendant to contract away liability" 131 and to insure that the principles of "both strict and vicarious liability remain intact in cases in which a defendant seeks to shift the responsibility for cost resulting from his ultrahazardous activity to others with whom he is involved in a business relationship." ${ }^{132}$ Although it might be argued that removing "the ability of . . . a defendant to contract away liability" could refer to past (as well as future) conduct, Representative Gore appears to be emphasizing the desire to prevent future generators from contracting away liability: he makes no mention of his amendment's applicability to past non-negligent generators such as Chemco. In addition, Representative Madigan implied that the Gore Amendment retained the defenses (including the "due care" defense) available to past waste generators that the House committee had included to prevent unfair retroactive liability. ${ }^{133}$

In contrast, retroactive application of the "due care" limitation is supported by Representative Gore's statement that the purpose

not be made out of the dictionary, the plain meaning of the use of the present tense and not the past tense indicates that section of statute applies only prospectively).

Once again, however, the Scarborough v. United States caution is in order: the tense of words in hastily drafted statutes may have been unintentional, making further inquiry into congressional intent necessary. 431 U.S. at 569-71. For such further inquiry, see infra text accompanying notes 131-39, 164-67.

130 Although the liability section as a whole should be held to apply retroactively, see supra text accompanying notes 50-81, this Comment argues that the Gore Amendment's limitation on the use of the statutory "due care" defense does not apply retroactively. The same argument regarding the Act's final language is also made. See infra text accompanying notes 164-67. Courts have held that when Congress applies an act retrospectively in one section, the absence of a clear statutory command that another section should apply retroactively precludes retroactive application of the second section. See In re Surface Mining Reg. Litig., 452 F. Supp. 327, 339 (D.D.C. 1978), aff'd in part, rev'd in part, 627 F.2d 1346 (D.C. Cir. 1980).

131126 Conc. Rec. H9463 (daily ed. Sept. 23, 1980) (emphasis added).

132 Id. (emphasis added).

133 Id. H9465-66. 
of his amendments to the House committee bill was to "remove the various escape hatches ... that would enable the parties who are most responsible for our hazardous waste problem to avoid liability." ${ }^{134}$ Here, he expresses a desire to impose strict liability on those most responsible for the hazardous waste problem existing at the time of the act, which would appear to include generators who contracted out disposal in the past. ${ }^{135}$

The ambiguity surrounding the interpretation of the Gore Amendment does not end with Gore's own statements. On one hand, the Chemical Manufacturers' Association, which had been adamantly opposed to retroactive strict liability for past waste generators, publicly supported the Gore Amendment, ${ }^{136}$ indicating that the "due care" standard, and not strict liability, was intended for past waste generators. On the other hand, Representative Jeffords indicated that the Gore Amendment's limitations on the "due care" defense were intended to apply retroactively as well as prospectively. ${ }^{137}$

The intended application of the Gore Amendment's limitations on the "due care" defense is at best unclear. For several reasons the better interpretation rejects retroactive application. Although care must be taken against relying too heavily on verb tense in hastily drafted statutes, ${ }^{138}$ the use of the present tense word "occurs," together with the ambiguous and seemingly contradictory legislative history and the strong presumption against retroactive construction, argue against retroactive application. A statute should not be applied retroactively when neither its language nor its legislative history strongly supports such a construction. ${ }^{130}$

The House passed the Gore Amendment by voice vote. ${ }^{140}$ Thus, the Superfund legislation it recommended to the Senate held future generators who engaged in Chemco-like third party

134 Id. H9465.

135 See supra text following note 12.

${ }^{136}$ A letter indicating such support was sent to Representative Florio, the principal House sponsor, and was reprinted in the Record by him. 126 Cong. REC. H9467 (daily ed. Sept. 23, 1980). But see 126 Conc. Rec. S14,963 (daily ed. Nov. 24, 1980), in which Senator Randolph stated that "I hear that industry support never really existed for the House superfund bill."

137126 Cong. REc. H9468 (daily ed. Sept. 23, 1980) (the Gore Amendment "limits the defense of intervening actions of a third party to instances where the defendant did not have a contractual relationship with the third party. . . .") (emphasis added).

138 Scarborough v. United States, 431 U.S. at 569-71.

139 See supra text accompanying notes 50-54.

140126 Cong. Rec. H9468 (daily ed. Sept. 23, 1980). 
disposal procedures strictly liable (subject to the causation requirement) for clean-up costs, but would have subjected past generators who contracted out their waste disposal to a lower "due care" standard.

It should be noted that adoption of the "prospective only" interpretation of the Gore language (as incorporated into the final version) would not permit all generators who contracted out their. waste disposal prior to the enactment of Superfund to escape liability. In fact, because such generators would still have to meet the "due care" standard of section $9607(\mathrm{~b})(3)$, it is likely that most would still be held liable. To satisfy the "due care" standard, generators must establish that they took reasonable precautions against foreseeable acts or omissions of the contractor. ${ }^{141}$. Thus, although the Gore Amendment permits past generators to utilize the "due care" defense, only those generators who carefully hired a contractor and monitored the waste disposal would be able to avoid liability under Superfund. Those generators who did not exercise. such due care in contracting out waste disposal, would still be held liable.

\section{The Senate Committee Version}

The House-passed bill sharply contrasted with the Senate committee version of Superfund. The Senate committee version would have held all hazardous waste generators-past, present, and future-strictly liable not only for clean-up costs, but for victim compensation as well, ${ }^{142}$ and it contained no proximate causation requirement and no third party defense at all. ${ }^{143}$ The tough Senate committee bill, however, was bound for almost certain defeat on the Senate floor, as a filibuster was threatened unless drastic changes were made to accommodate the demands of certain conservative Senators who wanted the liability provisions pared down..$^{144}$

141 See infra notes 169-7I and accompanying text.

142 Senate committee bill, supra note $115, \S 4(a)(1)-(2),(c), 126$ Cong. REc. at S14,940 (daily ed. Nov. 24, 1980).

143 Instead, the Senate committee bill specified which parties could be held jointly, severally, and strictly liable without exception. Senate committee bill, supra note $115, \$ 4($ a) (i)-(iv), 126 CoNG. Rec. S14,940 (daily ed. Nov. 24, 1980).

144 Senator Helms threatened to filibuster the Superfund bill. See "Superfund Cleanup Proposal Apparently Dead This Year," 38 Cong. Q. WeEkry ReP. 3378 (Nov. 15, 1980); "Superfund Action Slated; Bill Was Pulled on Nov. 20 Following GOP Objections," 38 CoNG. Q. WeEkLY ReP. 3413 (Nov. 22, 1980). Senator Helms also attempted to block Senator Byrd's motion to bring the bill up before the full Senate. Id. 


\section{The Senate Compromise Version}

Senate committee members, anxious to pass a Superfund bill before the close of the 96 th Congress, responded to the concerns of filibuster-threatening Senators by negotiating with them to produce a compromise version acceptable to everyone. ${ }^{145}$ The Senate compromise bill, which was negotiated behind the scenes and debated on the Senate floor for only a few hours, was passed by the Senate ${ }^{148}$ and later, in identical form, by the House just before the close of the 96th Congress. ${ }^{147}$

As stated earlier, ${ }^{148}$ the Senate compromise, which eventually became the Act, eliminated the term "strictly" from the liability provision. At least one commentator has concluded that this creates ambiguity regarding the Senate's intention to impose strict liability in any circumstances. ${ }^{149}$ The final version, however, also eliminated the House-passed version's proximate causation requirement by specifically naming the classes of individuals who could be held liable under the bill ${ }^{150}$ instead of stipulating that only parties who had "caused or contributed" to a release may be liable. ${ }^{151}$ All toxic waste generators who arranged for disposal by a third party clearly are covered by the final liability language, ${ }^{152}$ subject to specific statutory defenses, regardless of whether they "caused or contributed" to a release. The compromise bill abandoned the stringent strict and vicarious liability approach of the Senate committee bill, and adopted a third party "due care" defense that was identical to the House-passed Gore Amendment

145 See "Compromise Reached on "Superfund" Bill," 38 CoNg. Q. WEEkLY REP. 3435-37 (Nov. 29, 1980). Among the Senators involved in the compromise negotiations were Senators Byrd of West Virginia, Baker, Randolph, Stafford (Randolph and Stafford were the principal sponsors), Bradley, Moynihan, Helms, McClure, Domenici, and Dole. See 126 Cong. Rec. S14,948 (daily ed. Nov. 24, 1980) (remarks of Sens. Byrd and Baker).

146126 Cong. REG. S15,009 (daily ed. Nov. 24, 1980).

147126 CoNg. REc. H11,803 (daily ed. Dec. 3, 1980).

148 See supra text following note 111.

149 Note, Liability for Generators of Hazardous Waste: The Failure of Existing Enforcement Mechanisms, 69 GEO. L. REV. 1047, 1057 (1981).

150 Senate compromise bill, supra note $116, \$ 107(\mathrm{a})(1)-(4), 126$ CoNG. REc. at S14,993. This language was taken from the Senate committee version of S. 1480 . See supra note 143.

151 The "caused or contributed" language, it should be recalled, was used in the House-passed version. See House-passed bill, supra note $114, \$ 3071(\mathrm{a})(1)$.

152 Senate compromise bill, supra note 116, $\$ 107(a)(3), 126$ CoNG. REc. at S14,993. 
except for one very minor change and a more specific definition of the behavior comprising "due care." 153

\section{G. The Third Party "Due Care" Defense: Congress's Intended Meaning}

Given the preceding sketch of the Act's legislative history, it is possible to ascertain the intended meaning of the final version of the liability provisions and statutory defenses. First, although the term "strict liability" was eliminated from the final bill, it seems that this was a "concession" which gave up almost nothing. The definitional section of Superfund ${ }^{154}$ provides that the term "liable" shall be construed to be the standard of liability that obtains under section 311 of the Federal Water Pollution Control Act (FWPCA). 155 Indeed, one court has stated that " $t]$ he legislative history clearly establishes Congress' understanding that it was incorporating a standard of strict liability into [Superfund]." 156 As acknowledged by both of the principal sponsors of the Senate compromise measure, ${ }^{157}$ by Senator Helms, the chief Senate opposition spokesman, ${ }^{158}$ and by the floor manager of the measure during final House consideration, ${ }^{159}$ section 311 of the FWPCA has been interpreted by the courts as imposing strict liability unless the defendant can meet one of the specific statutory defenses under that Act. ${ }^{160}$ It was also agreed that the only de-

153 Senate compromise bill, supra note 116, $\$ 107(b)(3), 126$ CoNG. Rec. at S14,993. The text of this section, which was identical to the final version which became 42 U.S.C. $\$ 9607(\mathrm{~b})(3)$, is reprinted supra note 109 . Besides further elaborating on the meaning of "due care," the only change made from the Housepassed bill, which included the Gore Amendment, was to make available the "due care" defense to defendants only if the third party intervening was a common carrier by rail, the contractual relationship between that party and the defendant having arisen from a published tariff and acceptance by the rail carrier.

15442 U.S.C. $\$ 9601$ (32) (Supp. IV 1980).

16533 U.S.C. $\$ 1321(f)(1)$ (1976).

156 City of Philadelphia v. Stepan Chem. Co., 544 F. Supp. 1135, 1140 n.4 (E.D. Pa. 1982).

157126 Conc. REc. S14,964 (daily ed. Nov. 24, 1980) (remarks of Sen. Randolph); id. S15,008 (remarks of Sen. Stafford).

158 Id. S15,004 (remarks of Sen. Helms).

159126 Cong. Rec. H11,787 (daily ed. Dec. 3, 1980) (remarks of Rep. Florio).

160 See 126 Cong. REc. S14,964 (daily ed. Nov. 24, 1980) (remarks of Sen. Randolph) ( $\$ 311$ understood to impose strict liability); 126 CoNG. Rec. H11,787 (daily ed. Dec. 3, 1980) (remarks of Rep. Florio) ( $\$ 311$ imposes strict liability qualified only by the specific defenses stated in that Act; those defenses replaced 
fenses to Superfund liability would be the specific statutory defenses provided by the Superfund Act. ${ }^{101}$ Hence, the absence of the word "strict" in Superfund's final liability provision does not mean that the defendant can escape liability by pleading absence of negligence or any other common law defense to liability-he can escape liability only by utilizing one of the specific statutory defenses.

The third party "due care" defense adopted by the Senate and retained in the final bill thus takes on added significance. Because the defendant can no longer plead simple lack of causal connection to the discharge, as he could under the House-passed version, ${ }^{162}$ the defendant may avoid strict liability if his wastes are found in a site only by establishing that the release was caused solely by the type of third party described in the "due care" defense, ${ }^{163}$ and that "due care" was exercised in arranging for disposal. The focus of future litigation involving past and future generators who did not dispose of their wastes themselves should thus be upon whether they can utilize the third party defense. If they cannot, they will be strictly liable for clean-up costs associated with their wastes. If they can assert the defense, the analysis will shift to whether they exercised "due care" as envisioned by the Act.

As stated above, the final compromise version's third party defense was almost identical to the version that was adopted earlier by the House ${ }^{164}$ in that it permits a "due care" defense only for a defendant who can demonstrate that the release of hazardous waste was caused solely by "an act or omission of a third party other than an employee or agent of the defendant, or than one whose act or omission occurs in connection with a contractual relationship, existing directly or indirectly, with the defendant. . . " 165 Nothing was said in either the House or Senate indicating an intent to attach a meaning to this language different

here by specific Superfund defenses to strict liability); $i d$. H11,788 (letter from Mr. Alan Parker of the Justice Department reprinted as part of Rep. Florio's remarks) ( $\$ 311$ has been interpreted by the courts as imposing strict liability; cases cited).

161 See supra sources cited note 160.

162 House-passed bill, supra note $114, \$ 3071$ (a)(1).

163 Also, the act of God and act of war defenses were retained. 42 U.S.C. $\$ 9607$ (b)(1)-(2) (Supp. IV 1980).

164 See supra note 153 and accompanying text.

165 Senate compromise bill, supra note $116, \$ 107(b)(3), 126$ Conc. REC. at $\mathrm{S} 14,993$ (emphasis added). 
from that which it had when it originally passed the House as the Gore Amendment. ${ }^{168}$ Given the strong presumption against retroactive construction of statutes, ${ }^{167}$ the retention of the "prospective only" House language, together with Congress's subsequent silence indicates congressional intent to adopt the House's original "prospective only" intention. The present tense word "occurs" was used again in reference to the contractual relationship exception to the availability of the defense, so the inference again is that the exception is applicable only to future (post-enactment) generators, and that pre-enactment generators who contractually arranged for third party disposal may still utilize the "due care" defense.

There is, however, one further source of confusion regarding the scope of the third party "due care" defense. As has been argued, future waste generators may not utilize the defense if they were in a "direct or indirect" contractual relationship with the third party who caused the improper disposal. The bare language of the statute does not indicate what is meant by "indirect" contractual relationship. The only explanation of this phrase offered during its consideration is found in Representative Gore's remark that the third party "due care" defense should not be available if the party who caused the improper disposal was in a "business relationship" with the defendant. ${ }^{168}$ It seems clear that a subcontractor, even if not contractually related to the defendant/ generator, but instead to the party the defendant hired to dispose of his wastes, is still in a "business relationship" with the defendant even though not technically in a "contractual relationship." Gore's remarks imply that an expansive reading of the phrase "direct or indirect contractual relationship" was intended.

The final problem, then, is to determine what behavior constitutes "due care." The House-passed Gore Amendment retained the statutory definition of "due care" contained in the House committee bill, so the House committee report's description of "due care" is instructive. ${ }^{160}$ The Senate compromise bill, which became

${ }^{168}$ In fact, Representative Gore, the author of the House-passed version's liability language, indicated that the Senate compromise bill was "essentially the House bill." 126 Cong. REc. H11,801 (daily ed. Dec. 3, 1980).

187 See supra text accompanying notes 50-54.

168126 Cong. Rec. H9463 (daily ed. Sept. 23, 1980).

169 See H.R. ReP. No. 1016, supra note 8 at 34, reprinted in 1980 U.S. CoDE CoNG. \& AD. NEws at 6137 , where the committee states:

With respect to the third party defense, a defendant is also required to establish that he exercise [sic] due care with respect to the hazardous 
the final version, added further statutory elaboration to the "due care" definition, but it seems that it simply incorporated directly into the statute the criteria set forth in the House committee report. Under the final version, a defendant who has demonstrated that a qualified ${ }^{\mathbf{1 7 0}}$ third party was the sole cause of the release must also establish by a preponderance of the evidence that

(a) he exercised due care with respect to the hazardous substance concerned, taking into consideration the characteristics of such hazardous substance, in light of all relevant facts and circumstances, and (b) he took precautions against foreseeable acts or omissions of any such third party and the consequences that could foreseeably result from such acts or omissions. ${ }^{171}$

Absolutely nothing offering further clarification was said in the debates over this final language, but several hypothetical cases may better illustrate the meaning and applicability of the "due care" defense.

\section{Illustrative Hypothetical Cases}

First, assume the facts of the Chemco hypothetical exactly as posited above.172 If Chemco cannot utilize the "due care" defense,

waste concerned, taking into consideration the characteristics of such waste. The defendant must show that he exercised due care with respect to all reasonably foreseeable acts or omissions of a third party. For instance, in the case of a defendant generator, shipper, transporter, or disposer, the defendant must demonstrate that he exercised due care in the selection and instruction of a responsible contractor or other independent party engaged by such defendant or [sic] the transportation, storage, treatment, or disposal of the waste, provided adequate information as to the identity, quantity, composition, condition and characteristics of the waste to such person, and took reasonbale measures to assure or verify that such person properly carried out the activities for which he was engaged. Such defendant must also demonstrate that he properly labeled, loaded, and packaged the waste and properly equipped and maintained the container or facility used for the transportation, storage, treatment, or disposal of the waste. In general, the Committee intends that for a defendant to establish that he exercised due care, the defendant must demonstrate that he took all precautions with respect to the particular waste that a similarly situated reasonable and prudent person would have taken in light of all relevant facts and circumstances.

170 "Qualified," as used here, means a third party of the type not excluded by the statute.

171 Senate compromise bill, supra note $116, \S 107$ (b)(3), 126 CoNG. Rec. at S14,993. Compare the Act at 42 U.S.C. $\$ 9607$ (b)(3) (Supp. IV 1980).

172 See supra text following note 32 . 
it will be held strictly liable for clean-up costs caused by its wastes. In order to assert the defense, Chemco and all defendants must first show that the release of hazardous substances was caused solely by the actions or omissions of a third party. Since Chemco knew nothing about and had no connection with Flybynight's actions, it meets this initial test. Because the contractual relationship (if any) ${ }^{172}$ between Chemco and the third party which caused the release occurred prior to the enactment of Superfund, Chemco is not barred from asserting the "due care" defense by the "contractual relationship" exception, and thus may embark upon an attempt to prove it exercised "due care." Although Chemco's involvement in the 1974 disposal of Stickychem would not have been considered negligent behavior under 1974 law, ${ }^{174}$ it does not appear that Chemco can satisfy the tougher "due care" standard estab: lished by Superfund: Although Chemco chose a reliable contractor to conduct the disposal operation, and although the disposal contract contained a clause requiring safe disposal, Chemco took no further steps to ensure that its wastes ultimately would be disposed of safely. ${ }^{175}$ A reasonable, cautious generator could be expected to make at least an attempt to find out where its wastes were deposited, and would not disassociate itself from the disposal procedure immediately after hiring a contractor. Hence, although Chemco could assert the "due care" defense, it cannot meet the retroactively imposed "due care" requirements, and so would be responsible for clean-up costs expended.178

Had Chemco taken further precautions against unsafe disposal by Middleman and Flybynight, such as requiring them to submit proof that the wastes were disposed of correctly as contemplated under the contract, then Chemco would have been free from all liability under Superfund's "due care" defense even if the "proof" was in fact fraudulent and the wastes were in fact disposed of

173 See infra text accompanying notes $178-79$ for a discussion of whether a contractual relationship as defined by the Act existed between Chemco and the ultimate disposer of its wastes.

174 See supra text accompanying notes 38-39.

175 Such action is required under the House committee's description of what constitutes "due care," see supra note 169, which was incorporated into the statute in the final version. See supra text accompanying notes 169-71.

176 Even though strict liability is thus not imposed on past off-site generators, Superfund is still being applied retroactively because the "due care" standard is tougher than the standards that existed when Chemco acted; it is not merely duplicative of prior law. 
improperly by a contractually related third party. ${ }^{177}$ Hence, the third party "due care" defense exonerates past generators who contracted out their waste disposal as long as they took more precautions against foreseeable problems than did Chemco-even if their wastes ultimately cause damage. This would not be the result if the Act's "contractual relationship" limitation on the third party "due care" defense were applied retroactively, in which case these past generators would have been strictly liable under the Act.

In contrast, a post-enactment generator who exercised "due care" will still be liable under Superfund if the ultimate disposer of its wastes was in a Chemco-like contractual relationship with him. Such a future generator might argue that a far-removed disposer such as Flybynight is not in a "direct or indirect" contractual relationship with him. Clearly, however, if the generator knew that Middleman had subcontracted, then the subcontractor should be considered to be in an indirect contractual relationship with the generator. If the generator did not know that the middleman had subcontracted, then the existence of an indirect contractual relationship between the generator and the disposing subcontractor is arguably absent. Representative Gore's remark that the "contractual relationship" exception was intended to cover instances in which the disposer is in a "business relationship" with the generator, ${ }^{178}$ however, indicates that even an unknown subcontractor who disposes of a generator's wastes, and so has a "business relationship" with the generator, should be considered to be covered by the "contractual relationship" exception. Even if the "indirect contractual relationship" language is interpreted more narrowly-so that it does not cover unknown subcontractorsit seems that a generator who does not know what party ultimately disposed of its wastes (thus failing to oversee the disposal) would not meet the "due care" standard in any event. In order for a future generator to utilize the third party "due care" defense, then, the ultimate disposer's relationship with the generator must be quite attenuated ${ }^{179}$ and the generator must be able to show

177 Another situation in which a pre-enactment generator might escape liability by meeting the "due care" test is when he took all precautions against mishandling by the third party disposer, the disposer acted reasonably, and the wastes were disposed of in a method which at the time of disposal was thought to be perfectly safe, but is later discovered to have been a faulty disposal method.

178126 Cong. Rec. H9463 (daily ed. Sept. 23, 1980).

179 For example, the "due care" defense might be available if the defendant/ generator can establish that the third party who was the sole cause of the release 
good-reasons for failure to ensure that the strange third party acted properly. Congress intended to make it impossible for future generators to develop elaborate, multi-party disposal procedures in order to insulate themselves from strict liability under the Superfund Act.

\section{Can Generators be Held Jointly and Severally LIABLE UNDER THE SUPERFUND ACT?}

\section{A. Background: The Issue and the Problem}

Perhaps the most difficult issue presented by Superfund's liability provisions is whether Congress intended to authorize imposition of joint and several liability ${ }^{180}$ upon generators whose wastes comprise only a portion of the wastes at a particular dumpsite. At a typical abandoned dumpsite, there may be dozens of varieties of toxic wastes, generated by over one hundred different generators, not all of whom are solvent or easily locatable. In some cases, the wastes cleaned up at a site may be clearly traceable to a particular generator, in which case that generator will be held liable only for damages caused by his wastes. ${ }^{181}$ Quite often, however, damages have been caused by wastes mixed from several sources, making accurate apportionment of damages among the many generators quite difficult.

If Superfund's liability provisions can be interpreted properly as imposing joint and several liability, then generators who cannot prove what portion of the total damages was caused by their wastes will be liable for the entire clean-up. bill, including costs actually caused by other unknown or insolvent generators. ${ }^{182}$ Thus, the government will be able to recover the full amount of its clean-up

was a vandal who broke into a dumpsite and caused damage, or an unrelated.party such as a bulldozer operator at a certified site who negligently pushes against the lining of a pit containing the generator's wastes, causing the pit to leak.

180 For a concise definition of joint and several liability for multiple polluters, see Restatement (SECOND) of Torts $\$ 433 \mathrm{~B}(2)$ comment d, illustration 7 (1965). The modern principles of joint and several liability are also well summarized in the remarks of Representative Gore, 126 CoNG. REc. H99463-65 (daily ed. Sept. 23, 1980). See also infra text accompanying notes 182-84.

181 For example, it may be established that damages at a particular site were caused solely by leaking barrels, and those barrels may have been clearly labelled so that the contents and responsible generator can be easily identified. 7 (1965).

182 See Restatement (Second) of Torts $\$ 433 B(2)$ comment d, illustration 
costs, including costs actually caused by unknown or insolvent parties, from any one of the liable generators. ${ }^{183}$ After such recovery, the generators may seek to apportion the damages among themselves, which may involve new litigation..$^{184}$

If, however, Superfund was not intended to authorize imposition of joint and several liability upon individual generators, then the government will be able to recover from each generator only that portion of the total clean-up bill which it can prove was caused by that generator's wastes. Most importantly, the government will not be able to recover the costs of cleaning up wastes caused by unknown or insolvent generators. ${ }^{185}$ If such is the case, full recovery of government clean-up costs will be difficult, if not impossible, in many cases.

Not surprisingly, the language of the Superfund Act is ambiguous regarding imposition of joint and several liability. Unlike all three earlier versions of the bill, the final version makes no mention of joint and several liability, but merely holds generators and others "liable" for costs incurred."186 At least one commentator has, with some justification, interpreted the deletion of the terms "joint and several" as precluding the imposition of joint and several liability under. Superfund.187 Floor statements about the final version, however, make such an interpretation open to question, and necessitate another look at the complex legislative history of Superfund. Unfortunately, resolving the "joint and several liability" issue is even more difficult than ascertaining the scope and meaning of the third party "due care" defense.

183 Under the doctrine of "satisfaction," however, a plaintiff may recover from only one of several jointly and severally liable defendants, unless that defendant fails to pay in full. See remarks of Rep. Gore, supra note 180, 126 Cong. REc. at $\mathrm{H} 9453$.

184 Under the doctrine of "contribution," jointly and severally liable defendants may seek to apportion the total damages paid among themselves after the plaintiff has been paid in full. See id. The right of Superfund defendants to seek such post-payment contribution from co-defendants is guaranteed by the Superfund Act itself. 42 U.S.C. $\$ 9607$ (e)(2) (Supp. IV 1980).

186 To recover these costs, the government may sue the owner of the dump in which the wastes are cleaned up, or disposal outfits connected to the site. As has been noted, however, such parties are also frequently insolvent or impossible to locate. See supra text accompanying notes 12-13.

186 Compare the Act at 42 U.S.C. $\$ 9607$ (a)(4) (Supp. IV 1980) with the House committee bill, supra note $113, \$ 3071(\mathrm{a})(1)$, and with the House-passed bill, supra note $114, \$ 3071(\mathrm{a})(1)$, and with the Senate committee bill, supra
note $115 \$ 4(\mathrm{a})$.

187 See Note, supra note 149 , at 1058. 
Nevertheless, this Part argues that an interpretation of Congress's meaning regarding joint and several liability is possible: despite changes in the final statutory language, the final version was intended to preserve the standard set forth in the original Housepassed version, which again was drafted by Representative Gore. Congress intended to authorize imposition of joint and several liability in most circumstances in which the generator cannot prove his contribution, but left the courts with some discretion to apportion damages when the defendant/generator cannot do so.

\section{B. Early Legislative History}

\section{Initial House Consideration of the Joint and} Several Liability Issue

As the House committee had done with regard to the strict liability issue, its version of Superfund paid lip service to a tough (anti-industry) stance on joint and several liability, while in fact including provisions which required court apportionment of damages not readily attributable to one generator/defendant. ${ }^{188}$ In effect, then, the House committee version did not impose joint and several liability, since either the defendants or the courts were required to establish an apportionment scheme in every case.

Representative Gore, as he had done with the "due care" defense, exposed the true position of the House committee bill and introduced an amendment on the House floor to bring the House bill closer to imposing joint and several liability. Representative Gore argued that under modern common law standards, in cases in which damages are not clearly divisible among multiple defendants, the burden of proving that damages are capable of apportionment, and the amount attributable to each defendant, falls on each defendant. A defendant who fails to prove responsibility for only a limited portion of the damages is jointly and severally liable for all damages. ${ }^{189}$ As argued below, ${ }^{100}$ Representative Gore accurately characterized the modern common law rule in this area, although he failed to mention that a much more lenient traditional

188 The House committee bill, supra note 113, appears to impose joint and several liability in $\$ 3071(\mathrm{a})(1)$. However, the bill requires the court to apportion all unapportioned costs "to the maximum extent practicable." Id. $\S 3071$ (a)(2)(B).

189126 Cong. REc. H9463-65 (daily ed. Sept. 23, 1980).

190 See infra text accompanying notes 217-20. 
common-law rule is still followed in many jurisdictions. ${ }^{191}$ This failure, however, is understandable in light of Mr. Gore's objective: he wanted to strengthen the House bill as much as would be politically possible. ${ }^{192} \mathrm{So}$, in order to move closer to the tough modern common-law rule without appearing to do so, he presented the tough modern position as if it were universally followed, and described his amendment as a compromise between the modern common law rule and the quite lenient House committee version. ${ }^{193}$

The Gore compromise amendment did not require court apportionment of damages for defendant/generators who could not establish their contribution, and thus abandoned the lenient approach of the House committee. But neither did it forbid such court apportionment and require imposition of joint and several liability, the practice followed in modern common-law jurisdictions. Instead, the Gore Amendment permitted the court, at its discretion and in conjunction with several specific statutory guidelines, ${ }^{194}$ to apportion damages in appropriate cases, but to impose joint and several liability in all other cases where the statutory

191 See infra note 218 and accompanying text.

192126 Cong. Rec. H9465 (daily ed. Sept. 23, 1980) (remarks of Rep. Gore) ("Although I [prefer a stronger joint and several liability provision,] I offer my amendment in the spirit of compromise."). See also H.R. REP. No. 1016, supra note 8, at 64, reprinted in 1980 U.S. CODE CONG. \& AD. NEws at 6141, where Representative Gore stated his intention to offer House floor amendments designed to toughen up the House committee joint and several liability provisions. Gore).

193 See 126 Cong. REc. H9465 (daily ed. Sept. 23, 1980) (remarks of Rep.

194 See House-passed bill, supra note $114, \S 3071$ (a)(3)(B), 126 Cong. REc. at $\mathrm{H} 9461$. This section provides that:

the court may apportion the liability among the parties where deemed appropriate .... In apportioning liability ... the court may consider among other factors, the following:

(i) the ability of the parties to demonstrate that their contribution to a discharge, release, or disposal of a hazardous waste can be distinguished;

(ii) the amount of the hazardous waste involved;

(iii) the degree of toxicity of the hazardous waste involved;

(iv) the degree of involvement by the parties in the generation, transportation, treatment, storage, or disposal of the hazardous waste;

(v) the degree of care exercised by the parties with respect to the hazardous waste concerned, taking into account the characteristics of such hazardous waste; and

(vi) the degree of cooperation by the parties with Federal, State, or local officials to prevent any harm to the public health or the environment. 
apportionment criteria are not met by the defendant/generator. ${ }^{195}$ The Gore compromise amendment passed the House by voice vote on September $23 ; 1980 . .^{196}$

\section{The Senate Committee Version and the Senate Compromise Version}

With regard to joint and several liability the House-passed version (containing the Gore Amendment) was still more lenient toward generators than the Senate committee version. The Senate committee version, as with the strict liability issue, was the most stringent of the four versions. Basically, it would have codified the tough modern common-law rule requiring imposition of joint and several liability unless the defendant could clearly differentiate his contribution. ${ }^{197}$

Senate committee members interested in passage of Superfund legislation before the close of the 96th Congress realized that the tough committee language on joint and several liability would not survive the filibuster-threatening attacks of several influential Senators. ${ }^{198}$ Hence, during the formation of the Senate compromise version, which eventually became the Act, the Senators agreed to delete from the Senate bill (which was the starting point in the compromise negotiations) the terms "jointly and severally" and simply to hold generators and others "liable" for clean-up costs. ${ }^{109}$

\section{Interpretation of the Senate Compromise/Final Version Regarding Joint and Several Liability}

1. Conflicting Statements Made During Floor Consideration of the Final Language

The critical question with regard to the joint and several liability issue is how far from the Senate committee position the

105 House-passed bill, supra note 114, §3071(a)(3)(B).

196126 Cong. Rec. H9468 (daily ed. Sept. 23, 1980).

197 Senate Committee bill, supra note $115, \S 4($ a), 126 Cong. Rec. at S14,940. For a description of this section, see S. REP. No. 848, supra note 15, at 38-39.

198 See supra notes 144-45; see also 126 Conc. Rec. S14,968 (daily ed. Nov. 24,1980 ) (remarks of Sen. Stafford) (Senate committee bill will not pass because some Senators find its provisions too ambitious, but the compromise is weakened enough to pass).

190 Compare Senate committee bill, supra note 115, §4(a) with Senate compromise bill, supra note $116, \$ 107(a)$. 
committee members consented to move in order to achieve passage of the Act. Unfortunately, the debates following announcement of the compromise do not provide a clear answer. The chief committee spokesman, Senator Randolph, acknowledged that the terms "joint and several" had been deleted, and said that

issues of liability not resolved by this act, if any, shall be governed by traditional and evolving principles of common law. An example is joint and several liability. Any reference to these terms has been deleted, and the liability of joint tort feasors will be determined under common or previous statutory law [(section 311 of the Federal Water Pollution Control Act)].200

If Senator Randolph understood the common law the same way Representative Gore did-namely, as calling for imposition of joint and several liability-then it appears that nothing at all was given up. ${ }^{201}$ Indeed, both Senator Randolph and the chief Republican sponsor in the Senate, Senator Stafford, were careful to say that only the "terms" "joint and several" had been deleted,"02 leaving open the possibility that such liability was retained in substance. However, Senator Randolph described the deletion of the terms "joint and several" as a concession, 203 which indicates that something was in fact given up. Perhaps he understood that in some common-law jurisdictions, joint and several liability could not be imposed upon multiple generators, ${ }^{204}$ which would mean that the compromise's substitution of a common-law standard for the explicit and tough committee rule would not require all jurisdictions to impose joint and several liability under the statute-a "concession." Similarly, in discussing the many concessions made to achieve Superfund legislation in 1980, Senator Stafford stated that

200126 Cong. Rec. S14,964 (daily ed. Nov. 24, 1980).

201 Representative Gore characterized the common law as imposing joint and several liability in all cases in which the defendant could not prove his own contribution was distinct. See supra text accompanying notes 189-92. As argued infra text accompanying notes 216-20, however, this characterization reflects only the modern, progressive common law rule, which is followed only in some jurisdictions, and is therefore not a complete and accurate characterization of the "common law rule" in this area.

202126 Cong. Rec. S14,964 (daily ed. Nov. 24, 1980) (remarks of Sen. Randolph); id. S14,967 (remarks of Sen. Stafford).

203126 Conc. REC. S14,964 (daily ed. Nov. 24, 1980).

204 See infra text accompanying note 219. 
"75. percent of what we were seeking in [the Committee bill]" had been eliminated by the compromise. ${ }^{205}$ From these remarks alone, it would appear that the Senate version was diluted through inclusion of common-law restraints on the imposition of joint and several liability.

The chief opposition spokesman, Senator Helms, understood the compromise to have gone much further in weakening the joint and several liability provision. In fact, Senator Helms believed that the Senate compromise version was even weaker than the House-passed version. He clearly stated that in his view, the deletion of the terms "joint and several" and the use of the bare word "liable" with reference to section 311 of the FWPCA meant that the compromise did not impose joint and several liability. He stated:

It is very clear from the language of the StaffordRandolph substitute itself, from the legislative history, and from the liability provisions of section 311 of the Federal Water Pollution Control Act, that now the Stafford-Randolph bill does not in and of itself create joint and several liability. The Government can sue a defendant under the bill only for those costs and damages that it can prove were caused by the defendant's conduct. ${ }^{208}$

When the Senate compromise reached the House floor for final consideration, however, Senator Helms' interpretation was implicitly called into question by the legislation's chief House sponsor. The remarks of Representative Florio indicate that in his view, the Senate compromise could be interpreted as imposing joint and several liability-which would make the Senate Compromise even tougher than the House-passed version containing the Gore Amendment. ${ }^{207}$ While Florio agreed that under the final language joint and several liability should be governed by section 311 standards and "traditional and evolving principles of common law," 208 he inserted in the Congressional Record two legal opin-

205126 Cong. Rec. S14,967 (daily ed. Nov. 24, 1980).

206 Id. S15,004 (remarks of Sen. Helms) (emphasis added).

207 The Gore Amendment, it should be recalled, left the courts with the discretion not to impose joint and several liability in some circumstances. See supra text accompanying notes 193-95.

208126 Cong. REc. HII,787 (daily ed. Dec. 3, 1980). 
ions claiming that those standards call for imposition of joint and several liability, ${ }^{209}$ a strong indication that in Florio's view, the compromise imposed joint and several liability.

Representative Florio also made one statement, however, which implied that the Senate compromise, if not tougher on the joint and several liability issue than the House-passed bill, was at least equally as stringent. He stated that the House bill "provided for joint and several liability, but qualified that standard with two statutory apportionment provisions" and that the Senate compromise, "rather than announc[ing] the standard and then cut[ting] back on its applicability", simply refers to common law. ${ }^{210}$

In addition, Representative Florio remarked that Congress's intention was to encourage the development of federal common law on the issue of joint and several liability to discourage chemical companies from dumping in the states with the most lenient laws, ${ }^{211}$ such as states following the traditional common law rule. ${ }^{212}$ Florio, then, felt that the Act was intended to encourage the development of a uniform federal rule on joint and several liability which was at least as stringent, if not more so, than the Housepassed bill.

No Representative directly challenged Florio's assertion that the final version, with regard to joint and several liability, was as tough or tougher than the House-passed version. Although several Representatives claimed that the Senate compromise was weaker than the House-passed version in other important areas, not one asserted that the joint and several liability provision was weaker. Most significantly, however, several Representatives characterized the final version as essentially the same as the original House ver-

209 Representative Florio reprinted in the Record a letter from the Justice Department indicating that in its view the common law imposed joint and several liability upon generators who could not prove their contribution, and a letter from the Coast Guard indicating that in its view section 311 of the FWPCA might authorize imposition of joint and several liability in "appropriate circumstances." See 126 Cong. REC. HII,788-89 (daily ed. Dec. 3, 1980). Of course, these letters, both written by potential prosecutors under Superfund, are entitled to little, if any, weight as indications of the proper interpretation of the Act's joint and several liability provision. Their contents are significant only because they describe the probable views of Representative Florio.

210 Id. $\mathrm{H11}, 787$.

$211 I d$.

212 Such states would not impose joint and several liability upon multiple polluters. See infra text accompanying note 219. 
sion. ${ }^{213}$ Among this group was Representative Gore, the author of the original House-passed joint and several liability provision. ${ }^{214}$

\section{Proper Interpretation of the Final Version}

How should a court use this ambiguous legislative history in trying to determine whether imposition of joint and several liability is appropriate in a Superfund case involving multiple waste generators? The Senate seemed able to pass the Act only by referring definition of the joint and several liability standard to ambiguous common-law and statutory precedent, and by failing to challenge the view that this action could be interpreted as precluding imposition of joint and several liability. The House seemed able to pass the Act only after its chief proponent stressed that the final version was not as weak as it looked, and that in his view joint and several liability still could be imposed in most circumstances. Both Houses seemed able to agree only that the joint and several liability issue would be resolved by reference to section 311 and the common law.

Contrary to the conflicting claims of Senator Helms and Representative Florio, 215 however, an objective look at section 311 and the common law does not provide one consistent answer to a court trying to determine whether Congress intended to impose joint and several liability. No case under section 311 imposes joint and several liability for pollution clean-up, and the language of section 311 is ambiguous on its face. Despite Representative Gore's assertion to the contrary, ${ }^{216}$ the common law in this area is in a state of total disarray. ${ }^{217}$ Although the modern trend, which both Representatives Gore and Florio described, is toward imposition of joint and several liability for multiple polluters who cannot distinguish their contribution, only a limited number of jurisdictions adhere to this modern rule. ${ }^{218}$ Many jurisdictions still follow

213 See, e.g., 126 Cong. REc. H11,799 (daily ed. Dec. 3, 1980) (remarks of Rep. Jeffords) ("Although the Senate version does not contain the House language on the question of joint and several liability, the intent of the House provisions will largely be served ...."); id. H11,796 (remarks of Rep. Mikulski). bill.").

214126 Id. HIl,801 (remarks of Rep. Gore) ("This is essentially the House

215 See supra text accompanying notes 206, and 207-09.

216 See supra text accompanying notes 189-93.

217 For a discussion of state common law regarding multiple tortfeasors, see Note, Joint and Several Liability for Hazardous Waste Releases Under Superfund, 68 VA. L. Rev. 1157, 1166-73 (1982).

218 Restatement (SECOND) OF Torts $\$ 433 B(2)$ comment d, illustration 7 (1965); see, e.g., Michie v. Great Lakes Steel Div., 495 F.2d 213 (6th Cir. 1974) 
the old Restatement rule that holds a polluter liable only for the portion of damages that the plaintiff (government) can prove were caused by the defendant's wastes. ${ }^{219}$ Both Prosser and American Jurisprudence $2 d$ stress that there is a split in the law in this area. ${ }^{20}$ Hence, characterizing "traditional and evolving principles of common law" in this area as either calling for or rejecting imposition of joint and several liability would be one-sided and inaccurate.

Given the inadequacy of the guidelines suggested in the legislative history, it is arguable that Congress simply intended to leave entirely to the courts the question whether joint and several liability should apply under a given set of circumstances. Senator Randolph stated that joint and several liability may have been one issue "not resolved by this Act," 221 and one Representative claimed that Congress had "avoided" the liability issues. ${ }^{222}$

There are, however, two overriding problems with the contention that Congress intended simply to leave the joint and several liability issue to the courts. First, Representative Florio clearly stated that it was Congress's intent to encourage the development of a uniform federal standard so that chemical manufacturers and disposers would not seek out lenient states in which to dispose of their wastes. ${ }^{23}$ The split in the common law regarding joint and several liability impedes the clearly intended congressional

(burden of proof on the defendant to show what portion of total pollution it contributed; if it cannot establish its contribution, it is jointly and severally liable for total damages); Phillips Petroleum Co. v. Hardee, 189 F.2d 205 (5th Cir. 1951) (joint and several liability where damages are indivisible); Azure v. City of Billings, 182 Mont. 234, 596 P.2d 460 (1979); Velsicol Chem. Corp. v. Rowe, 543 S.W.2d 337 (Tenn. 1976); Landers v. East Tex. Salt Water Disposal Co., 151 Tex. 251, 248 S.W.2d 731 (1952).

219 Restatement of Torts $\$ 881$ (1939); see e.g., Pacific Gas \& Elec. Co. v. Fibreboard Prod. Inc., 116 F. Supp. 377, 378 n.2 (N.D. Cal. 1953) (California follows rule that does not impose joint and several liability upon independent tortfeasors); Vaughn v. Burnette, 211 Ga. 206, 84 S.E.2d 568, 569 (1954) (court must apportion damages among several defendants who flooded plaintiff's lot); Maas v. Perkins, 42 Wash. 2d 38, 253 P.2d 427 (1953); O'Neal v. Southern Carbon Co., 216 La. 96, 43 So. 2d 230 (1949); Masonite Corp. v. Steede, 198 Miss. 530, 23 So. $2 d 756,759$ (1945) (defendant whose pollution allegedly contributed to the destruction of plaintiff's fishing resort business can only be held liable for proportionate part of total damages suffered).

220 W. Prosser, HandBoOK OF the Law of Torts $\$ 52$ (4th ed. 1971); 61A AM. JUR. 2D Pollution Control $\$ 551$ (1981).

221 See supra text accompanying note 200.

222126 Cong. Rec. H11,801 (daily ed. Dec. 3, 1980) (remarks of Rep. Brown). 223 See supra text accompanying notes 211-12. 
goal of developing a uniform federal rule if the issue is left to individual courts. Second, the argument that Congress intended to give no guidance to the courts on this issue ignores the fact that several key legislators strongly felt that the word "liable" as used in the statute did reflect a statutory answer to the joint and several liability problem-although they disagreed as to what that answer was. ${ }^{224}$ So it seems that Congress did not intend to leave the issue completely to the courts. Rather, the "federal common law" regarding generator liability ${ }^{225}$ is to be developed by the courts in a manner consistent with the intent of Congress as embodied in the final compromise version.

The Senators and Representatives commenting on the final compromise language of the liability section generally viewed it as less strict than the Senate committee version, which called for strict, joint, and several liability, ${ }^{228}$ and more in line with the original House-passed version which incorporated the Gore compromise ${ }^{227}$ on joint and several liability. ${ }^{228}$ Only Senator Helms directly contradicted this view, ${ }^{229}$ and even though Helms played an important role in the formation of the Senate compromise, there are compelling reasons to accord his interpretation limited weight. ${ }^{230}$ Similarly, Representative Florio's somewhat obtuse

224 Senator Helms believed the Act precluded imposition of joint and several liability, see supra text accompanying note 206, whereas Representative Florio indicated that the Act required imposition of joint and several liability by referring to common-law and previous statutory standards, see supra text accompanying notes 207-09.

225 The creation of "federal common law" involves problems beyond the scope of this Comment. Such law in the environmental contert is considered in Note, supra note 217, at 1173-82. A more general consideration is found in Note, The Federal Common Law, 82 Harv. L. Rev. 1512 (1969). This Comment argues that the "federal common law" of joint and several liability that will be developed in Superfund cases should be informed primarily by congressional directives that, though not explicit, nevertheless are present and can be discerned by examining closely the history surrounding the final compromise. See infra text accompanying notes $226-40$ and following note 240 .

226 See supra text accompanying note 197.

227 See supra notes 194-96 and accompanying text.

228 Both Senators Randolph and Stafford viewed the final language as less stringent than the original Senate committee version. See supra text accompanying notes 203-05. Representatives Jeffords, Mikulski, Gore, and, possibly, Florio viewed the final version as the same as the House-passed version on the joint and several liability issue. See supra notes $210,213 \& 214$ and accompanying text.

229 See supra text accompanying note 206.

230 Senator Helms was the only legislator to claim that the final language was weaker than the House-passed version on the joint and several liability issue. But 
intimation that the final version may have been even tougher on the joint and several liability issue than the House-passed version ${ }^{231}$ should not be read as the conclusive interpretation. ${ }^{232}$ Instead, it appears that the majority of Congress believed that the final compromise bill should be regarded as handling the joint and several liability issue in a moderate matter similar to the House-passed Gore compromise. ${ }^{233}$

That the majority of those involved in the final debate equated the final measure with the House-passed version is not surprising, for both measures were developed as a compromise between the same two polar positions. ${ }^{234}$ Concededly, the Senate

Helms, who ultimately voted against passage of the Act because he believed its liability provisions were too stringent, see 126 CoNG. REc. S14,988 (daily ed. Nov. 24, 1980), had reason to exaggerate how much was given up on the joint and several liability issue by the compromise version. He undoubtedly knew, as a member of the Senate compromise committee, that the compromise measure, having been accepted by the Senate leadership, see 126 Conc. REc. S14,948 (daily ed. Nov. 24, 1980) (remarks of Sens. Byrd and Baker), would pass. Because he had agreed not to filibuster, see supra notes $144-45$ and accompanying text, he could best accomplish his goal of weakening the liability provisions of an Act he knew would pass over his objections by reading into the Record his lenient interpretation of the meaning of the compromise agreement.

In addition, it should be noted that the Supreme Court has held that the statements of opponents of a bill are not an authoritative guide to construction. Schwegmann Bros. v. Calvert Distillers Corp., 341 U.S. 384, 394-95 (1951); cf. Arizona v. California, 373 U.S. 546, 583 n.85 (1963).

231 See supra text accompanying notes 207-10.

232 First, Representative Florio made at least one remark which indicated that even he thought the final version was essentially the same as the House-passed Gore compromise on the joint and several liability issue. See supra text accompanying note 210. Second, Representative Florio may have had a tactical reason to exaggerate the toughness of the final version on the joint and several liability issue. As a strong supporter of prompt passage of Superfund legislation, see 126 Conc. REc. H11,787 (daily ed. Dec. 3, 1980), he undoubtedly was concerned that passage might be stalled by Representatives who felt that the Senate compromise had weakened the legislation in critical areas. See, e.g., 126 Cong. Rec. Hll,795 (daily ed. Dec. 3, 1980) (remarks of Rep. Snyder); id. (remarks of Rep. Biaggi); id. (remarks of Rep. Pickle). It was thus in his interest to exaggerate the strength of the final joint and several liability provision.

Finally, the Supreme Court has held that the "remarks of a single legislator, even the sponsor, are not controlling in analyzing legislative history. . . . [Such] statement[s] must be considered with ... the statements of other Congressmen ...." Chrysler Corp. v. Brown, 441 U.S. 281, 311 (1979). This caution seems particularly applicable to Florio's statements, as he was the only legislator to view the final compromise as conceivably imposing joint and several liability according to the strict modern common law rule.

233 See supra note 228.

234 When the full House first faced the joint and several liability issue, Representative Gore characterized his amendment as a compromise between the modern common-law rule (joint and several liability) and the House committee bill (practically speaking, no joint and several liability). See supra text accompanying notes 
did not simply adopt the Gore language without change, choosing instead to compromise through obfuscation by deleting the terms "joint and several". But it appears that the legislation's sponsors had compelling tactical reasons to forego adoption of the House language. ${ }^{235}$ It is thus reasonable to conclude that the best interpretation of the final language is that Congress intended it to embody the same compromise as the House-passed Gore Amendment on joint and several liability.

Moreover, because the Gore Amendment permits the courts to be flexible within certain guidelines, ${ }^{236}$ looking to the Gore language for guidance does not involve the replacement of concededly ambiguous final language with a rigid answer to the joint and several liability issue. Under the Gore Amendment as passed by the House, ${ }^{237}$ generators who can conclusively prove their contribution are not subject to joint and several liability, but are only liable for a discrete portion of the clean-up costs. ${ }^{238}$ Generators who cannot conclusively segregate their contribution generally will be held jointly and severally liable, but the court is given important discretionary authority to excuse such generators from joint and several liability if it determines that they can meet certain specifically delineated criteria. ${ }^{239}$ Thus, Congress has left the courts with some, but

189-93. When the full Senate first confronted the issue, it formed a committee to compromise between the Senate committee bill (joint and several liability) and the position of the filibuster-threatening Senator Helms (no joint and several liability). See supra text accompanying notes $197-99$ and supra note 206.

235 Senator Helms, who was threatening a filibuster, believed that joint and several liability was inappropriate under any circumstances, see 126 Conc. REc. S15,004 (daily ed. Nov. 24, 1980), and so must have been opposed to the Housepassed Gore language. By declining to adopt the explicit Gore language, the majority of Senators and committee members favoring prompt passage could avoid a filibuster by appeasing Senator Helms with ambiguous liability language which Helms could publicly interpret as being quite lenient. Helm's interpretation could then be counterbalanced by more liberal interpretations, especially in the House (where the rules forbid a filibuster), and the final language would ultimately be interpreted to be at least as tough regarding joint and several liability as was the House-passed version containing the Gore Amendment. Thus, the majority of Senators favoring prompt passage of Superfund could achieve the same joint and several liability standard as contained in the House-passed version while avoiding a conservative filibuster.

236 See supra note 194 and text accompanying notes 194-95.

237 See 126 Cong. Rec. H9461, 9468 (daily ed. Sept. 23, 1980).

238 Such generators are excused from joint and several liability under both the traditional and modern approaches, so their status here is not in dispute. The traditional and modern approaches differ with regard to the treatment of generators who cannot conclusively prove what portion of wastes resulted from their chemicals-but such proof is often quite difficult, especially when old, leaking sites containing wastes from many generators are involved.

239 See supra note 194 and text accompanying notes 194-95. 
not complete, discretion in determining whether to hold Superfund generators jointly and severally liable, a result which itself can be viewed as a compromise between the two possible interpretations of congressional intent on the issue of how much discretion should be left to the courts. ${ }^{240}$ The Gore approach would encourage federal courts inclined to follow the old common law disfavoring joint and several liability to move toward its imposition in many cases; the Gore approach requires imposition of joint and several liability upon defendants who cannot prove their contribution unless the court feels such imposition would be inappropriate under the specific guidelines provided. Conversely, the Gore approach encourages courts inclined to follow the modern common. law rule to relax that rule at times, enabling some defendant/ generators to show that joint and several liability is inappropriate; a court has discretion, within the established guidelines, to excuse small contributors from joint and several liability. Thus, courts that otherwise would choose one of the polar positions would be encouraged, but not required, to moderate their positions in Superfund cases, and over time a fairly specific and uniform federal rule on joint and several liability in Superfund cases would emerge, consistent with the Gore guidelines and the intent of Congress.

\section{Conclusion}

This Comment has made three principal arguments regarding the application of Superfund's liability provisions to past generators of hazardous waste. First, although Superfund's liability provisions must be applied retroactively in order to impose clean-up liability upon past non-negligent generators who disposed of their wastes in off-site facilities, such application is authorized by the Act and is not violative of any constitutional prohibition. Courts thus should not hesitate to apply Superfund retroactively, and should not entertain time-consuming constitutional attacks on the fairness of the Act's liability provisions.

Second, although future generators who engage in contractually arranged off-site disposal practices are subject to strict liability under the Act for almost any clean-up costs incurred where their wastes are involved, pre-enactment waste generators who used identical third party disposal procedures are subject only to a "due care" standard. Although the "due care" standard is tougher than 
the negligence standard that existed at the time such past waste generation and disposal occurred, it is weaker than a strict liability standard, and may prove to be an obstacle to full recovery of clean-up costs at some abandoned sites. In such cases, state enforcement agencies may be able to finance clean-up by suing past generators under state common law, which has moved recently toward declaring hazardous waste generation an ultrahazardous activity, thus holding generators strictly and vicariously liable for all damages caused by their wastes. ${ }^{241}$ Political factors compelled Congress to shy away from imposing such a standard upon past generators under Superfund, and courts should not ignore statutory construction principles regarding retroactivity and claim that the statute precludes use of the defense by both past and future generators using contractual third party disposal procedures.

Finally, this Comment has argued that, under Superfund, Congress intended hazardous waste generators who cannot prove what contribution to total damages were caused by their wastes to be jointly and severally liable only if they cannot meet certain criteria for relief from such liability. The courts should not seize isolated interpretations of the ambiguous statutory language on this issue to justify strict adherence to either the old or the modern common-law rule regarding joint and several liability, as some commentators have done. ${ }^{242}$ Nor should they simply conclude that because the "purpose" of the Act was to clean up abandoned sites, the Act should be read as imposing joint and several liability simply because such an interpretation would most quickly and easily achieve this goal.243 This interpretation does not accord the legislative history its proper weight, and completely ignores the last-minute compromise which clearly diluted the toughness of the joint and several liability provisions to some degree. Instead, courts should attempt earnestly to interpret the joint and several liability provision in the manner that most accurately reflects Congress's intent when it passed the Act, a task that requires an understanding of the politics and strategy involved in the Act's consideration. Although in some cases Congress's intended standard (as embodied in the Gore guidelines) might make imposition of

241 See supra notes 38-39 and accompanying text.

242 See, e.g., Meyer, supra note 25, at $700 \mathrm{n} .64$ (joint and several liability imposed under the Act since common law imposes such liability); Note, supra note 149, at 1058 n.65 (statute makes no provision for joint and several liability).

243 This argument is made in Note, supra note 217 , at 1182-95. 
joint and several liability inappropriate, thereby making it more difficult for the government to recover fully its clean-up costs, courts should nevertheless remain true to that intention while developing a congressionally mandated uniform and detailed federal rule on joint and several liability. 